\title{
Fold interference pattern at the top of basement domes and apparent vertical extrusion of HP rocks (Ambin and South Vanoise massifs, Western Alps)
}

\author{
J. Ganne ${ }^{\mathrm{a}, *}$, J.-M. Bertrand ${ }^{\mathrm{b}}$, S. Fudral ${ }^{\mathrm{c}}$ \\ ${ }^{a}$ Australian Crustal Research Centre, School of Geiosciences, Monash University, PO Box 28E, Melbourne, Victoria 3800, Australia \\ ${ }^{\mathrm{b}}$ Laboratoire de Géodynamique des Chaînes Alpines, CNRS UMR 5025, Université de Savoie, F 73376 le Bourget du Lac cédex, France \\ ${ }^{\mathrm{c}}$ EDYTEM, CNRS, Université de Savoie, Domaine Universitaire, F-73376, France
}

The Ambin and South Vanoise Briançonnais basement domes, located within the HP metamorphic zone, were chosen for a reappraisal of the early tectonic evolution of the Internal Alps in their western segment. Finite strain analyses have shown that HP rocks were exhumed in two main successive stages, more or less expressed according to their structural position in the massifs. A partitioning of deformation, from core to rim of the domes, is thus evidenced. The $\mathrm{D}_{1}$ stage was roughly coeval with the observed peak metamorphic conditions and corresponds in the core of the Ambin dome, to a non-coaxial regime with dominant horizontal shortening and $\mathrm{N}$ to NW movement direction. The $\mathrm{D}_{2}$ stage, well-expressed in the upper part of the domes, took place under low-blueschist facies conditions and culminated under greenschist facies conditions. It developed a retrogressive foliation and pervasive E-verging shear-zones at all scales that locally define major $\Phi_{2}$ tectonic contacts. The $\mathrm{D}_{2}$ shearing is responsible for the development of spectacular $\mathrm{F}_{1}-\mathrm{F}_{2}$ fold interference structures recognised in the western part of the South Vanoise dome. In this area, we interpret the steeply-dipping HP-fabric $\left(\mathrm{S}_{1}\right)$ defining the axial planes of the first generation of now-upright folds $\left(\mathrm{F}_{1}\right)$ as linked to an early flat-lying nappe edifice $\left(\Phi_{1}\right)$ subsequently steepened by the $\mathrm{D}_{2}$ shearing. Geometry and kinematic characteristics for the early $\mathrm{D}_{1}$ nappe-forming event are strongly consistent with most evolutionary models assuming that oceanic to European and Apulian crust-derived nappes were initially exhumed during $\mathrm{N}$ to $\mathrm{NW}$-verging overthrusting events, synthetic to the subduction. They tend also to suggest that the Penninic HP-units may have suffered an early exhumation by low-angle thrusting, rather than by vertical extrusion.

Keywords: High-grade rock exhumation; Fold interference pattern; Partitioning of deformation; Western Alps; Penninic domain

\section{Introduction}

The arcuate orogenic belt of the western Alps is located at the convergent boundary between Europe and the African promontory of Adria. The orogen is commonly regarded as a classic collisional belt representing the closure of one or more ocean basins from the Late Cretaceous to Late Eocene ( $~ 90-35 \mathrm{Ma})$ and the subsequent progressive indentation of Adria into Europe (e.g. Platt et al., 1989). The internal part of the orogen (the 'Penninic Alps') consists of a series

\footnotetext{
* Corresponding author. Tel.: +61-3-9905-3097

E-mail address: jerome.ganne@mail.earth.monash.edu.au (J. Ganne).
}

of continental terranes (the Austroalpine-Sesia zone, the Briançonnais zone and the Internal Massifs), which are aligned as arcuate ribbons parallel to the strike of the orogen (Fig. 1). These terranes are separated from each other and from the stable foreland by several ophiolitic suture (Piemont, Antrona(?), Valais), which mark the locations of consumed Jurassic to Cretaceous ocean basins (Stampfli et al., 1998; Rosenbaum and Lister, 2005).

Occurrences of high-pressure (HP) and ultra-highpressure (UHP) rocks in the internal western Alps indicate that during orogenesis rock units were subjected to burial at depths of $40-100 \mathrm{~km}$. HP and/or UHP metamorphism affected each zone within the Penninic Alps at different 


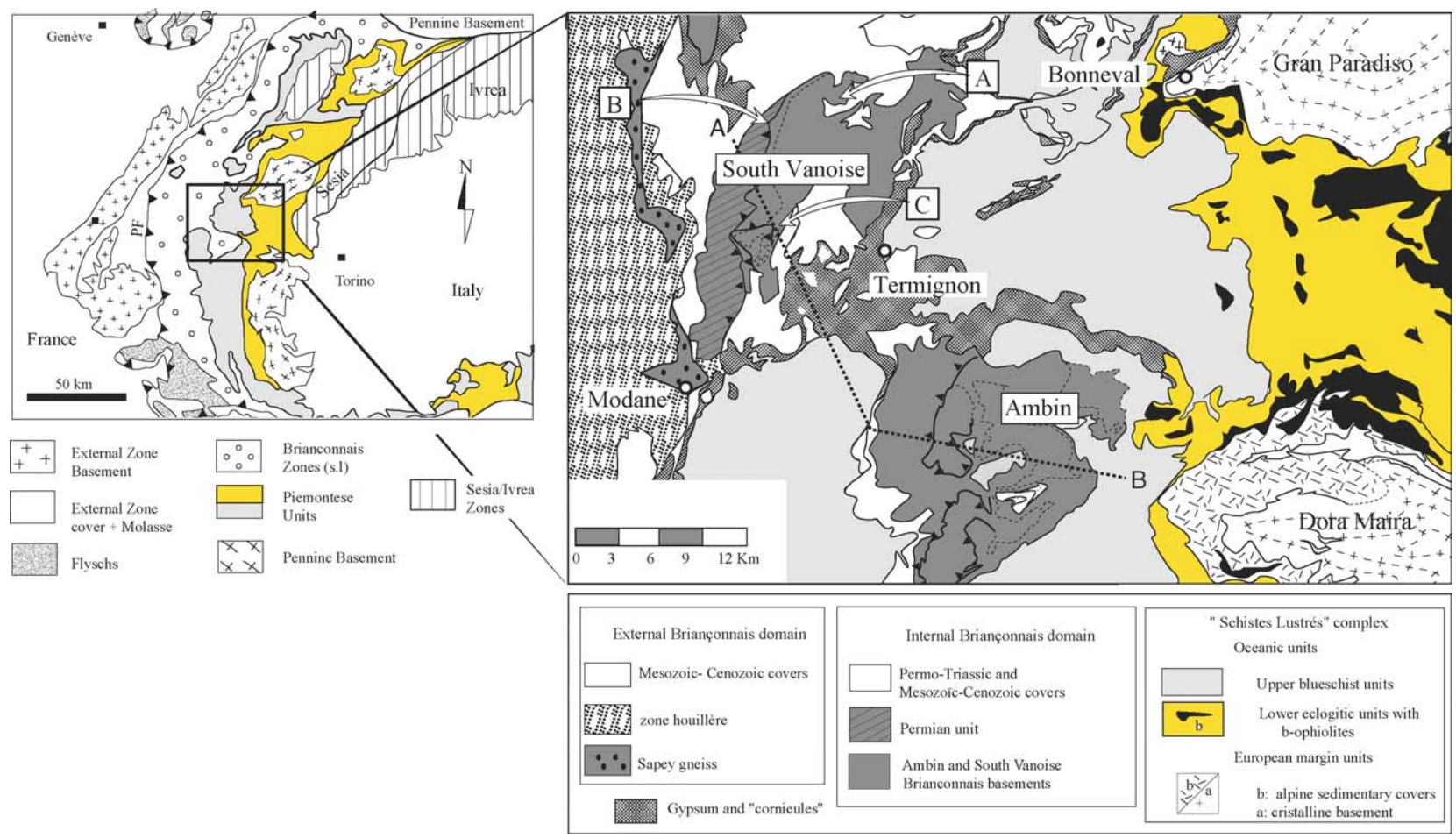

Fig. 1. Geological map of the internal zones of the western Alps showing location of the Ambin and South Vanoise massifs. Thick lines with barbules: Everging 'backthrusts' discussed in the text: (A) Mont Pelve-Plateau de la Réchasse area; (B) La Valette area; (C) Fond d'Aussois area;. PF: Penninic Front.

stages of Alpine orogenesis (e.g. 70-65 Ma in the Sesia Zone, $\sim 44 \mathrm{Ma}$ in the Piemont zone, 45-36 Ma in the Briançonnais, and $\sim 42-35 \mathrm{Ma}$ in the Internal Massifs: Duchêne et al., 1997; Gebauer et al., 1997; Markley et al., 1998; Rubatto, 1998; Rubatto and Gebauer, 1999; Rubatto and Hermann, 2003; Meffan-Main et al., 2004). These ages suggest that Alpine orogeny may have evolved during episodic collisional events associated with accretion of different continental terranes (Lister et al., 2001; Rosenbaum and Lister, 2004). In this tectonic configuration, it is possible that Briançonnais, Piemont and Internal Massifs HP rocks formed as the result of an Eocene-Oligocene accretionary event, and were subsequently rapidly exhumed (Freeman et al., 1997; Rubatto and Hermann, 2001).

These ages tend also to suggest that HP or UHP rocks may have suffered a vertical extrusion-or a fast exhumation of rigid indenters in a softer environment (Allemand and Lardeaux, 1997; Schwartz et al., 2001) rather than low-angle motion by thrusting (Escher and Beaumont, 1997). In a more general way, the dilemma between supporters of vertical or horizontal related exhumation models result for a large part from the difficulty to infer the geometry of the deep-seated structures at the time of their formation. Structural and microstructural characteristics of the exhumation of the Briançonnais, Piemont and Internal Massifs high pressure rocks, during a complex deformation event globally called $\mathrm{D}_{1}$, are still disputed (Caron, 1974, 1977; Platt et al., 1989; Philippot, 1990; Agard et al., 2001). The kinematic of early deformation in these high pressure domains is poorly known and previous observations are often contradictory (Choukroune et al. (1986) or Platt et al. (1989) for a different interpretation), due to the post- $\mathrm{D}_{1}$ intense transposition features (Lefèvre and Michard, 1976; Philippot, 1990; Henry et al., 1993; Rolland et al., 2000; Agard et al., 2001; Wheeler et al., 2001; Reddy et al., 2003).

The Ambin and south Vanoise massifs, occupying a key position among the metamorphic units of the Internal Western Alps (Briançonnais and Piemont domains), were chosen as case studies to track the rare traces of this early alpine deformation. They are almost perfect basement domes that preserve HP-LT metamorphic assemblages. The initial geometry and strain regime of the $\mathrm{D}_{1}$ event, together with associated metamorphic assemblages, were reconstructed in the basement units of the two massifs. This reconstruction will be used for comparison with the available alpine evolutionary models (Stampfli et al., 1998) and to discuss consequences on the knowledge of exhumation processes (e.g. Platt (1993) for a review). This structural study has been undertaken and performed in the light of a recent chemical characterisation of alpine and prealpine Briançonnais garnets (Ganne et al., 2003) that led us to re-interpret the garnet-bearing fabric recognised in the core of the domes as linked to an early alpine deformation now defined as $\mathrm{D}_{1}$ (this study). 


\section{Geological setting of the Ambin and South Vanoise massifs}

The Ambin and South Vanoise basement massifs belong to the Briançonnais Zone, which is interpreted by most workers as palaeogeographically derived from the European passive margin (Lemoine and de Graciansky, 1988) or as an allochthonous terrane (Stampfli, 1993; Bertrand et al., 2000). They form dome-shaped basement windows (Fig. 1) cropping out beneath allochthonous metamorphic envelopes of various origins (Briançonnais Mesozoic units, ocean-derived Liguria-Piemont zone units). Almost parallel envelopes define the domes (Fig. 2a). Structural discontinuities separate lithological groups previously defined by Michel (1957) and Gay (1971). They are, from bottom to top: (1) the Claréa and Ambin Groups forming the pre-Permian basement whose origin and pre-alpine tectonometamorphic evolution are still poorly know; (2) the Etache Group, considered as Permo-Triassic in age and overlain by metasediments of Triassic to Eocene age; (3) the 'Schistes Lustrés complex', consisting of Jurassic to Cretaceous allochthonous metasediments of the Liguria-Piemont zone (Caron, 1977).

\section{Structural evolution of the Ambin massif}

The petro-structural evolution of the Ambin massif has already been addressed in a previous article (Ganne et al., 2004) and will be used, as a point of reference and comparison, to discuss the tectonic pattern on the Fond d'Aussois area (South Vanoise massif). To simplify the nomenclature and description on Fig. 2b, we have distinguished three main litho-tectonic units within the different envelopes of the Ambin massif, which have been called 'Nappes'. The latter are separated by major discontinuities, which are thought to have a tectonometamorphic significance (Ganne et al., 2003). These three nappes are, from bottom to top (Fig. 2c): (1) the Claréa Nappe, consisting only of pre-Permian micaschists (Claréa Group); (2) the Ambin Nappe, consisting of slices of pre-Permian basement (Claréa + Ambin Groups), PermoTriassic and Triassic to Eocene metasediments; (3) the 'Schistes Lustrés' Nappe, consisting only of oceanic metasediments from the Liguria-Piemont basin. This lithostratigraphy has been established on the basis of published work, especially from the Lanslebourg-Mont d'Ambin (Fudral et al., 1994) and Modane (Debelmas et al., 1989) $1 / 50,000$ map sheets.

Finite strain analyses have revealed the existence of three ductile to brittle-ductile deformation phases, characterised by specific types and/or vergence of structures. Structural and metamorphic data are presented in terms of ductile $\mathrm{D}_{1}$, $D_{2}$ and brittle-ductile $D_{3}$ events (Fig. 3) for the purpose of comparison with earlier descriptions in adjacent areas. A critical appraisal of this classification is beyond the scope of this study and is deferred to another paper (Ganne et al., 2004). The most obvious structures recognisable in the Ambin and Schistes Lustrés Nappes are those related to the $\mathrm{D}_{2}\left(+\mathrm{D}_{3}\right)$ retromorphic deformations. These ductile to brittle-ductile shear events overprint pre-existing fabrics such as $S_{1}\left(D_{1}\right.$ event), which is the earliest alpine foliation clearly distinguishable from $\mathrm{S}_{-1}$ pre-Alpine fabrics and linked to the HP metamorphic peak $\left(\mathrm{M}_{1}\right)$. The $\mathrm{D}_{1}$ event is well preserved in the Claréa Nappe, i.e. in the deeper part of the Ambin massif. The Claréa Nappe shows little evidence for $\mathrm{D}_{2}$ deformation.

\section{1. $D_{1}$ deformation structures in the Claréa Nappe}

In the internal western Alps, most kinematic indicators for the early tectonic stages are ambiguous and/or obscured by later reworking (Platt and Lister, 1985a,b; Philippot, 1990; Henry et al., 1993; Michard et al., 1996). In the Ambin and Schistes Lustrés Nappes, the pre- $\mathrm{L}_{2}$ lineation trend cannot be determined precisely. Refolded fold axes, the most conspicuous feature of a $D_{1}$ stage, are nevertheless common (Caron, 1977; Allenbach, 1982). Conversely, most folds observed in the Claréa Nappe (e.g. folds of mafic layers; Fig. 2c), seem to predate the $\mathrm{D}_{2}$ stage. They correspond to a strong ductile deformation, responsible for the main foliation (Fig. 4a and b). Usually, the main foliation dips gently and follows the overall dome pattern. This fabric overprints an earlier fabric occurring now in microlithons (Fig. 4d). Previous authors (Borghi et al., 1999, and references therein) attributed both fabrics to pre-alpine events. Indeed, in the albite-biotite-bearing micaschists (about $70 \%$ of the Claréa Nappe), muscovite and presumed pre-alpine large biotite are similarly present in both fabrics, the growth of blue amphibole (very scarce in the albitebiotite-bearing micaschists) being interpreted as static (Monié, 1990). New observations show that in the Claréa micaschists, multi-stage garnet (Ganne et al., 2003) shows a pre-alpine core and an alpine rim systematically wrapped by the main fabric of the micaschists (Fig. 4c and d). At microscope scale, the clear-cut boundary between the two garnet components is outlined by an inclusion-rim: a very dense concentration of tiny inclusions mainly constituted by quartz, biotite and pre-alpine muscovite. However, newly crystallised alpine minerals such as blue amphibole and phengite also occur in small quantities, associated with older inherited minerals, suggesting that a strong shearing event of alpine age may have occurred under HP conditions when the rims crystallised. This observation strongly suggests that the gently dipping fabric recognised in most of the Claréa Nappe is linked to an early alpine deformation now defined as $D_{1}$ (Ganne et al., 2003). The corresponding $S_{1}$ fabric is parallel to the axial plane of $F_{1}$ folds that deform assumed pre-alpine structures $\left(\mathrm{S}_{-1}\right.$; Fig. $\left.4 \mathrm{a}\right)$.

$\mathrm{S}_{1}$ is defined in the glaucophane-bearing micaschists (about $30 \%$ of the Claréa Nappe) by HP minerals ( $\mathrm{Fe}, \mathrm{Ca}$ garnets, Si-rich phengite, chloritoid, glaucophane, jadeite, 

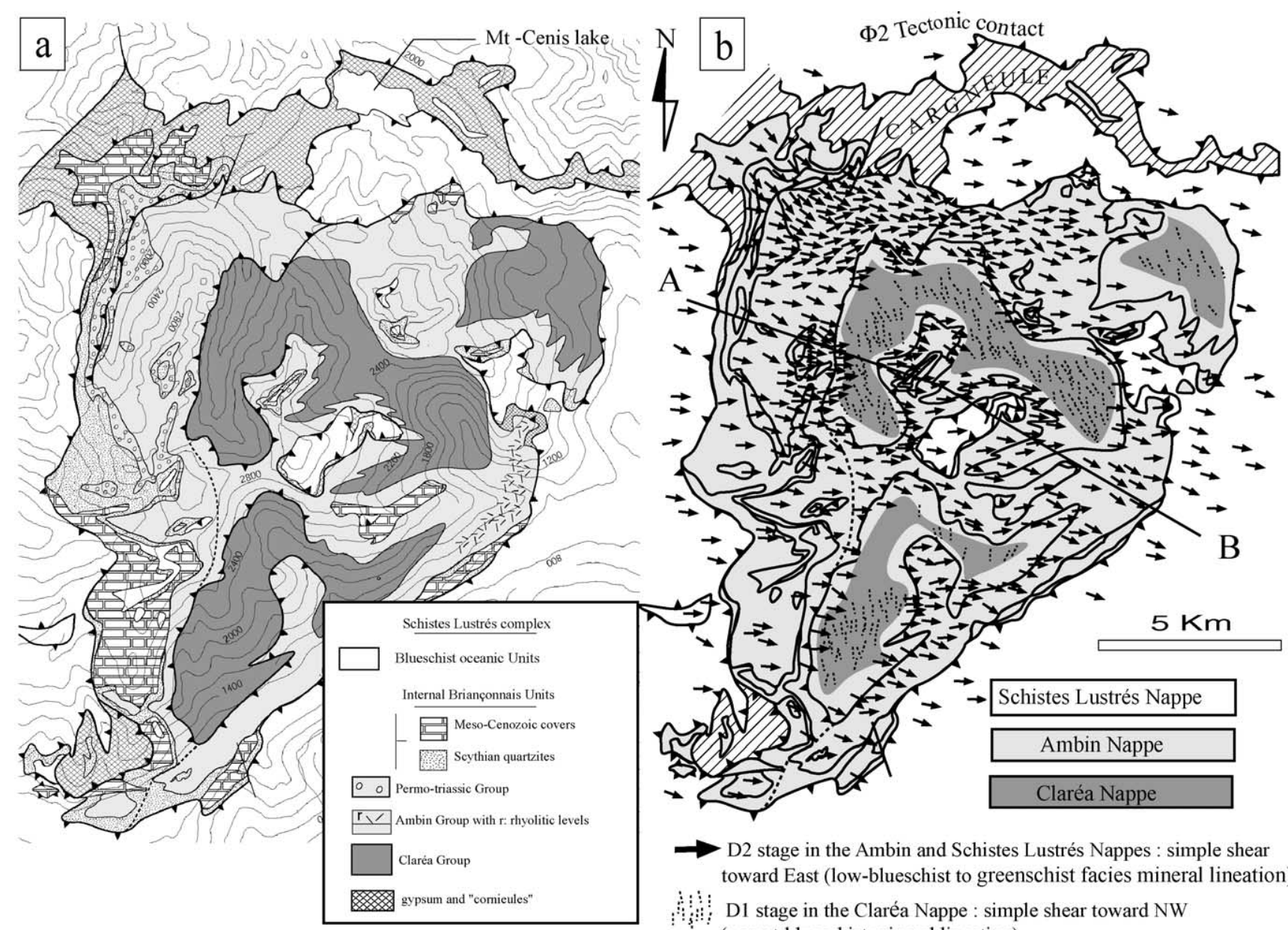

D2 stage in the Ambin and Schistes Lustrés Nappes : simple shear toward East (low-blueschist to greenschist facies mineral lineation)

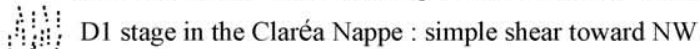
(garnet-blueschist mineral lineation)

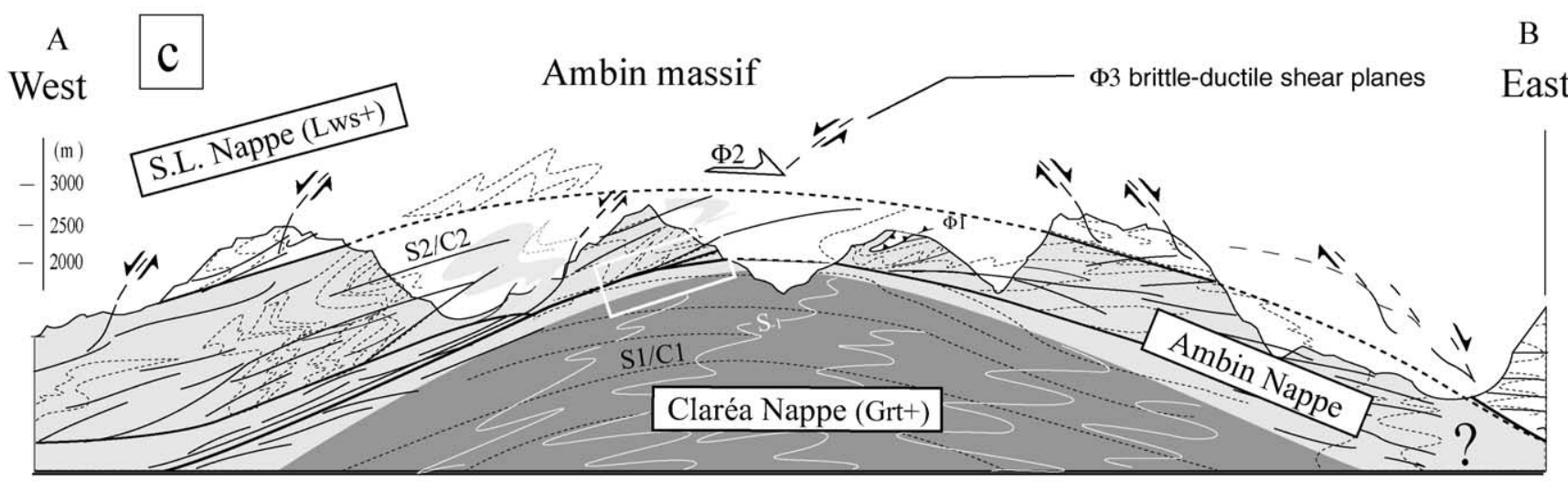

Ambin Nappe shear zones (slices of basement, oceanic and Briançonnais covers) : Tectono-metamorphic boundary, equivalent to a 'garnet isograd', between the Claréa Nappe (basement ; Garnet +) and the Schistes Lustrés (S.L) Nappe (oceanic covers; Lawsonite +). The white boxe images the structural position of the Fond d'Aussois area (South Vanoise massif).

Fig. 2. (a) Geological sketch map of the Ambin massif (see Fig. 1 for location) based on mapping by Gay (1971), modified. (b) Structural map of the Ambin massif (personal data). This consists of three superimposed tectonic nappes: the Claréa, Ambin and Schistes Lustrés Nappes. The upper part of the Ambin massif is affected by a pervasive $\mathrm{D}_{2}$ shearing event with top-to-the-E movement direction. This $\mathrm{D}_{2}$ shearing is well expressed in the Ambin Nappe where both oceanic and Briançonnais cover are strongly deformed with slices of basement (Claréa + Ambin Groups). The deeper part of the massif (i.e. the Claréa Nappe), consisting exclusively of the Claréa Group, preserves early HP structures $\left(\mathrm{D}_{1}\right)$. (c) E-W structural cross-section through the Ambin massif (see (a) for location) showing the relationships between Claréa, Ambin and Schistes Lustrés Nappes. The litho-tectonic characteristics of the Fond d'Aussois area are similar to those recognised at the Claréa-Ambin Nappes transition, in the Ambin massif (white box): a mixing between scarce slices of Mesozoic covers and dominant imbricated folds of pre-Permian basement (Claréa and Ambin Groups). 


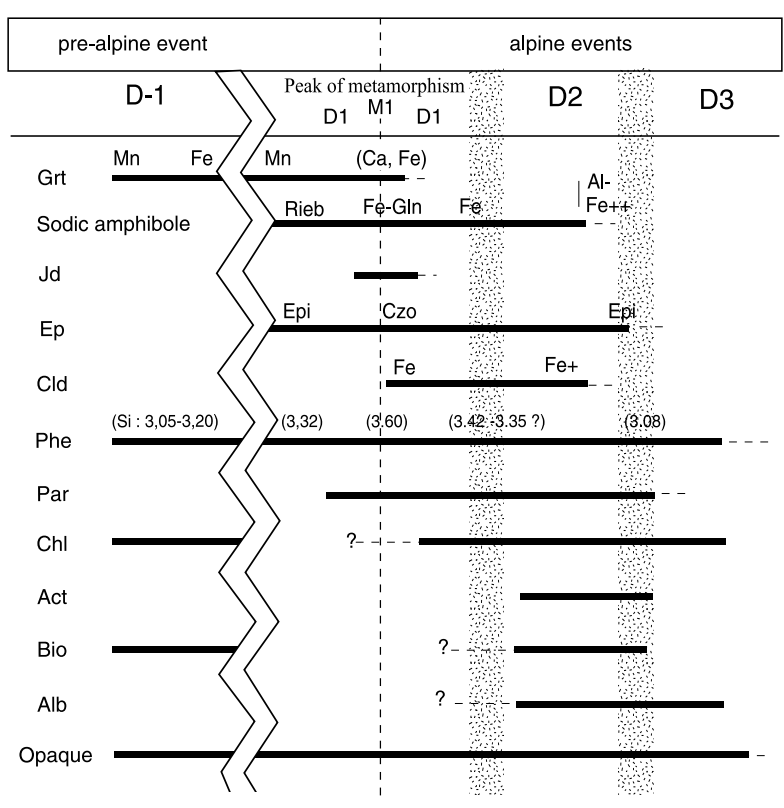

Fig. 3. Crystallisation-deformation relationships in the Ambin massif (alpine and pre-alpine minerals). Grt $=$ garnet; $\mathrm{Jd}=$ jadeite; $\mathrm{Ep}($ Epi $)=$ epidote; $\mathrm{Phe}=$ phengite $\mathrm{Par}=$ paragonite $\mathrm{Cld}=$ chloritoid Rieb $=$ riebeckite; $\mathrm{Gln}=$ glaucophane $; \mathrm{Czo}=$ clinozoisite $; \mathrm{Chl}=$ chlorite $; \mathrm{Act}=$ actinolite $\mathrm{Bio}=$ biotite $\mathrm{Alb}=$ albite

paragonite, clinozoisite). Late chloritoid and less-Si substituted phengite are also associated with the $S_{1}$ fabric and indicate that decompression occurred during the final stage of $\mathrm{D}_{1}$ (exhumation process). Glaucophane-phengite \pm chloritoid define a mineral lineation on the $\mathrm{S}_{1}$ foliation. Its average N-S trend is often scattered by $\mathrm{D}_{2}\left( \pm 40^{\circ}\right)$, especially at the top of the Claréa Nappe. Field observations suggest that $\mathrm{F}_{1}$ folds correspond to B-type folds (e.g. Ramsay and Huber, 1983) with near-E-W-trending axes but it was impossible to relate the mesoscopic $\mathrm{D}_{1}$ structures to larger-scale features. $\mathrm{D}_{1}$ deformation appears non-coaxial in the glaucophane-bearing micaschist as shown by meso- and microscale structures. However, the coexistence of E-Wtrending B-type folds and $\mathrm{N}-\mathrm{S}$ mineral lineations suggests that stretching was not very strong. Several microstructural evidences suggest that the $\mathrm{L}_{1}$ lineation corresponds to the projection, on the $S_{1}$ plane, of the movement direction during a $D_{1}$ shearing event: asymmetric boudinage of $S_{1}$; asymmetric fabrics of phengite, chloritoid and glaucophane wrapped as pressure shadows or strain fringes around garnets (Fig. 4b); rotation of quartz and inherited plagioclase; sigmoid features developed in syn-kinematic garnet; trails of opaque minerals underlining $S_{1}$ and refolded during a continuous top-to-the-N shearing event (Ganne et al., 2004); folded inclusions within syn-kinematic glaucophane.

\subsection{Ductile $D_{2}$ structures in the Ambin and Schistes Lustrés Nappes}

The most obvious ductile structures-foliation and small-scale shear zones aligned by micas-are those related to $D_{2}$. The $D_{2}$ stage is characterised by well-developed shear planes (Fig. 2b) and by the gently-dipping $S_{2}$ foliation observed in most of the Ambin and Schistes Lustrés Nappes. The corresponding deformation pattern may be described as ductile syn-foliation $\mathrm{C}_{2}-\mathrm{S}_{2}$ shear bands (Berthé et al., 1979), which correspond to type-I C-S bands (Lister and Snoke, 1984). The angle between the $C_{2}$ and $S_{2}$ planes is usually low (typically $10-20^{\circ}$ ). $\mathrm{S}_{2}$ is either parallel to axial planes of $\mathrm{F}_{2}$ folds and deforming an earlier $\mathrm{S}_{1}$ foliation, or corresponds to a composite surface resulting from transposition of $S_{1}$. In the latter case, $S_{1}$ is preserved in micro-folds within $S_{2}$-defined microlithons. Mesoscale $F_{2}$ folds are mostly observed in the well-layered Claréa Group, at the bottom of the Ambin Nappe (Fig. 2c), whilst the composite foliation and tight isoclinal $\mathrm{F}_{2}$ folds rather characterise the Ambin Group. $\mathrm{F}_{2}$ folds deform indifferently the earlier $\mathrm{S}_{0} / \mathrm{S}_{1}$ fabric and the main tectonic $\Phi_{1}$ contact, which separates the basement and Mesozoic cover from the Schistes Lustrés (Malavielle, 1982; Fig. 2c). Fold axes are horizontal and N$\mathrm{S}$ - to NW-SE-trending. At all scales penetrative ductile shear zones dip toward $\mathrm{W}$ or $\mathrm{E}$ according to the general shape of the dome. Shear bands and $\mathrm{S}_{2} / \mathrm{C}_{2}$ fish-like structures always indicate a top-to-E movement. The $\Phi_{2}$ tectonic contacts actually correspond to strong concentrations of $\mathrm{C}_{2}-\mathrm{S}_{2}$ shear bands (Fig. 2c) together with the appearance of mylonitic fabrics. An E-W mineral and stretching lineation is ubiquitous on $\mathrm{C}_{2}$ and $\mathrm{S}_{2}$ planes (Fig. $2 b)$. It is marked by elongated quartz grains or stretched phengite-chlorite-epidote-actinolite fibrous aggregates. At the bottom of the Ambin Nappe, $\mathrm{S}_{2}$ and $\mathrm{L}_{2}$ are defined by mixed aggregates of chlorite and actinolite where blue amphibole is often broken. In a few cases, the growth of blue amphibole seems to be contemporaneous with the $\mathrm{D}_{2}$ stage. Indeed, in the Schistes Lustrés Nappe, blue amphibole together with chloritoid defines a strong lineation in the $\mathrm{S}_{2}$ foliation, with a remarkably consistent N.100 trend $\left(<20^{\circ}\right.$ spread). The $\mathrm{S}_{2}$ foliation reworks here an earlier HPLT alpine fabric (Caron, 1977). Such evidence argues for recrystallisation and/or growth of blue amphibole during $\mathrm{D}_{2}$.

\subsection{Ductile to brittle $D_{3}$ structures in the Ambin and Schistes Lustrés Nappes}

$\mathrm{D}_{3}$ deformation features include large-scale open folds affecting the previous $S_{2}$ foliation and a locally developed micaceous crenulation. $\mathrm{D}_{3}$ is commonly marked in the Schistes Lustrés Nappe by small-scale N-S-trending crenulation-folds overprinting the $\mathrm{D}_{2}$ structures. In the carbonaceous Briançonnais covers, $\mathrm{D}_{3}$ is outlined by the crystallisation of quartz-chlorite-phengite and/or calcite veins. Brittle-ductile shear bands $\left(C_{3}\right)$ crosscut the $D_{2}$ fabrics at high angle. An E-W-trending stretching lineation is observed on most $\mathrm{C}_{3}$ planes, marked by small stretched quartz and calcite grains but also by phengite and chlorite. Kinematic indicators-conjugate extensional $\mathrm{C}_{3}$ shear 

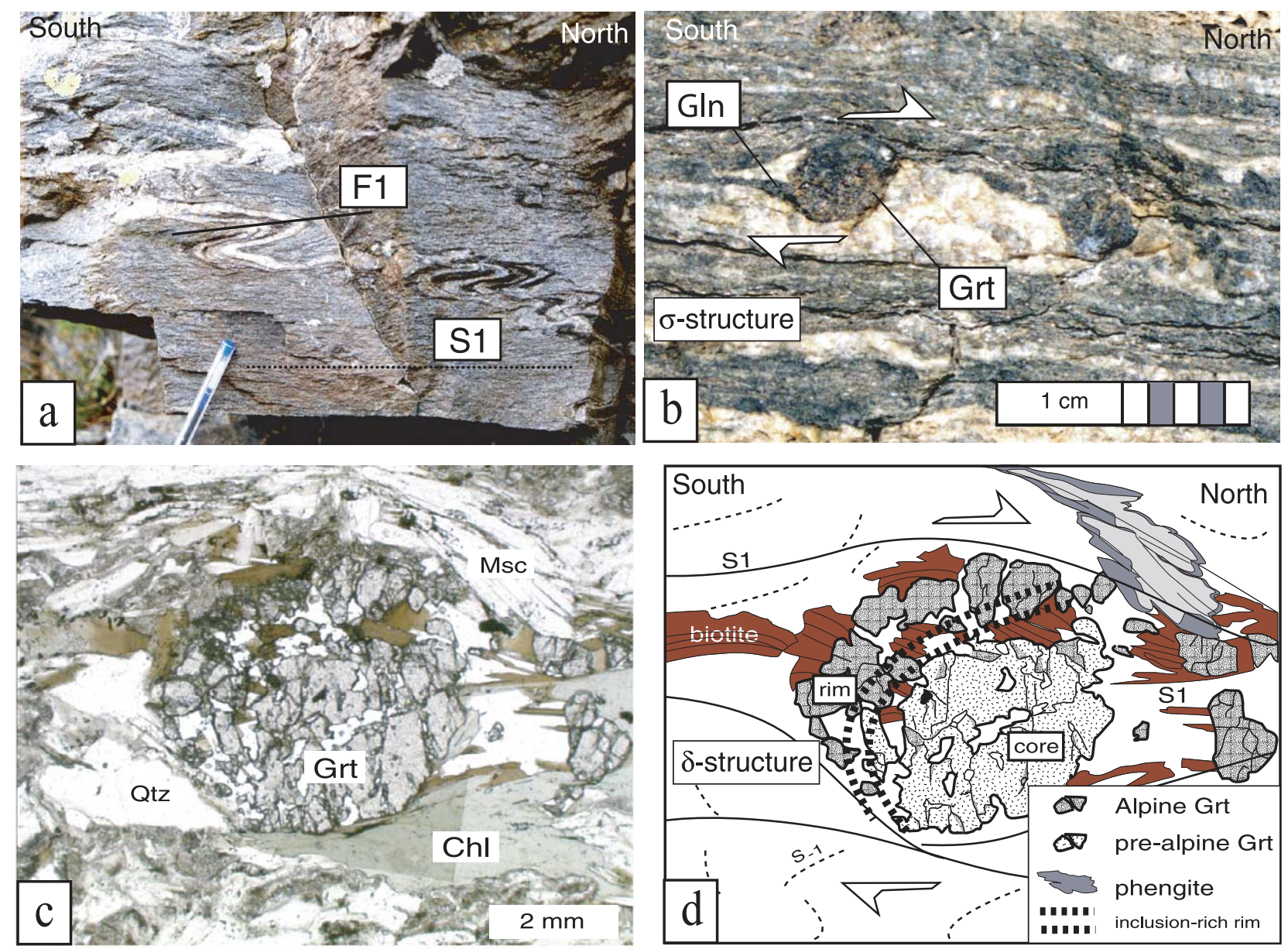

Fig. 4. $\mathrm{D}_{1}$ deformation structures in the Claréa Group. (a) Pre-alpine mineral foliation of biotite (dark bands)—muscovite-quartz refolded by alpine $\mathrm{F}_{1}$ fold; alpine HP mineral assemblage grows in the $S_{1}$ axial planar foliation (albite-biotite-bearing micaschists). (b) Alpine syn-kinematic garnet (Grt) surrounded by HP minerals forming a strain fringe of glaucophane (Gln) \pm chloritoid \pm phengite (glaucophane-bearing micaschists). (c) and (d) Textural relations between alpine rim and pre-alpine cores of garnet (sample Ga-22, Ambin massif). The inclusion-poor garnet core is fragmented during the $\mathrm{D}_{1}$ north-verging simple shear deformation regime and wrapped by the main alpine fabric $\left(\mathrm{S}_{1}\right)$. Inclusion-rich rims of alpine garnets and high-Si substituted phengites grow at the expense of the pre-alpine clasts, forming a strain fringe. Relics of muscovites (Msc), outlining the pre-alpine foliation $\left(\mathrm{S}_{-1}\right)$, are marginally replaced by phengite. Chl: chlorite; Qtz: quartz. Note the microstructural difference between the $\sigma$-structure on (b) and $\delta$-structure on (d).

bands, symmetric micro-boudinage of pre- $\mathrm{D}_{3}$ crystals of poihiloblastic albite, deformed vertical veins-point to an overall-coaxial deformation. Along the western edge of the Ambin dome, extensional $\mathrm{C}_{3} / \Phi_{3}$ shear planes preferentially indicate a top-to-the- $\mathrm{W}$ movement whilst east of the dome, the $\mathrm{C}_{3} / \Phi_{3}$ shear planes preferentially are top-to-the-E (Fig. 2c). This feature clearly indicates that the dome structure was formed during the $\mathrm{D}_{3}$ stage.

\section{Structural evolution of the South Vanoise massif: insights from the Fond d'Aussois area}

The structural setting of the South Vanoise massif is mainly controlled by an E-verging shear deformation (classically called 'backthrusting' by different authors, e.g. Platt and Lister, 1985a,b) which produced a complex stack of large-scale tectonic slices. Thus, the Fond d'Aussois area (' $\mathrm{C}$ ' in Figs. 1 and 5) shows the superposition of three main tectonic slices delimited by shear zones (Fig. 6).

The 'Fond d'Aussois' shear zone, which has a W-NW shallow-dipping appearance, cross-cuts basement units and Briançonnais cover and individualizes two slices:

(i) A lower slice mainly constituted of paleozoic basement units (Claréa and Ambin Groups), associated with a few thinned shreds of mesosoic covers (Permo-Triassic to Triassic located at the north of the Plan d'Amont dam). The lower part of this slice is unknown.

(ii) A medium slice in which are mixed, from west to east, basement units, Triassic cover units and Liassic units belonging to the 'Dent Parrachée nappe' (Platt et al., 1989). This latter consists of Norian to Eocene sediments (Deville, 1987). The Fond d'Aussois shear zone extends further to the east, in the Fournache 


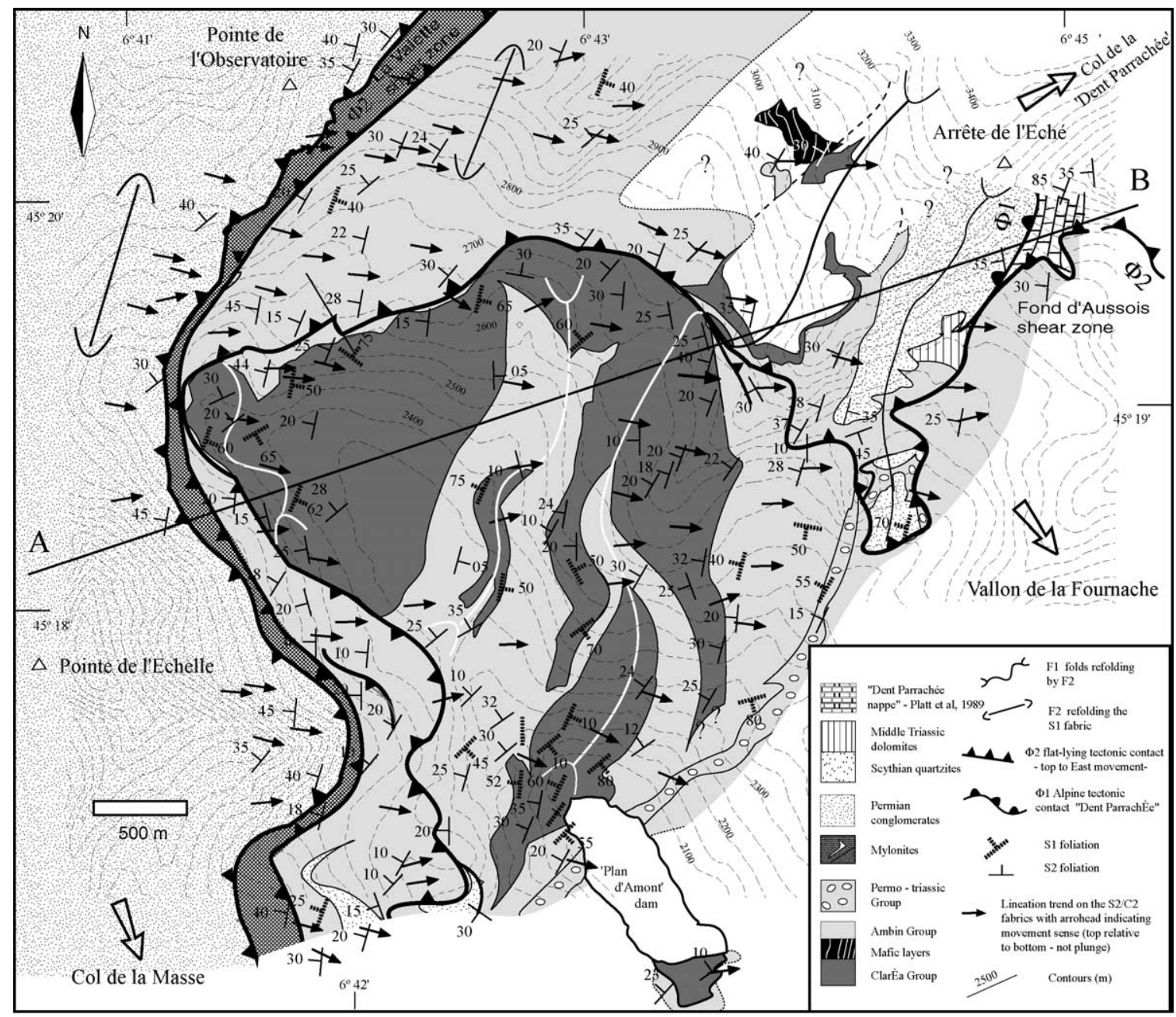

Fig. 5. Geological map of the Fond d'Aussois area; location: 'C' in Fig. 1.

valley, cropping out below the Scythian quartzites of l'Arête de l'Eché (Fig. 5).

The 'La Valette' shear zone corresponds to the 'thrust' (Platt et al., 1989) of La Pointe de l'Echelle-Rateau d'Aussois (upper slice exclusively constituted by conclomeratic Permian) at the top of the medium slice. This 'thrust' is accommodated by a thick level $(1 \sim 3 \mathrm{~m})$ of chlorito-albitic schists (corresponding probably to mylonites of basement) that can be followed from the Col de la Masse in the south, to the Col de la Valette-Col du Tambour (Fig. 7) in the north, through the Col du Génépy. This mylonitic contact outlines the limit of extension toward the east of the conglomeratic Permian of Vanoise (Fig. 8), socalled 'Permien du col d'Aussois' (Ellenberger, 1958; Détraz and Loubat, 1984). The 'La Valette' shear zone extends geometrically above the carbonaceous level of the Dent Parrachée. Its prolongation toward the east (or of one of its ramifications) probably passes below the important tectonic pile of the Mont Pelve-Plateau de la Réchasse quartzites ('A' in Fig. 1) and Liassic calcareous levels of $L a$ Grande Casse (work in progress).

\section{1. $D_{1}$ and $D_{2}$ ductile stages}

Thus, the tectonic pattern of the Fond d'Aussois area is comparable to the lower part of the Ambin Nappe, defined in the Ambin massif (Fig. 2c): a complex litho-tectonic interface in which scarce slices of Mesozoic covers are mixed with imbricated folds of pre-Permian basement (Fig. $6)$. The two main ductile stages of deformation, $D_{1}$ and $D_{2}$, previously described in the Ambin Nappe, have been recognized in the slices of Fond d'Aussois. The expression and style of structures is strongly dependent on the nature of the rocks.

The Claréa Group is marked by a penetrative and noncoaxial $\mathrm{D}_{1}$ deformation, syn-metamorphic to crystallisation of alpine garnet (helicitic growth of this latter). The steeplydipping $S_{1}$ foliation is outlined by elongated crystals of glaucophane and chloritoid, between which occur grains of clinozoisite, jadeite or sphène (Fig. 9a). Fibres of phengite have crystallised parallel to glaucophane and chloritoid crystals, sometimes at the expenses of pre-alpine muscovites reworked in the $S_{1}$ foliation (Fig. 9b). Prealpine fabric is badly preserved: $\mathrm{S}_{-1}$ is commonly observed 


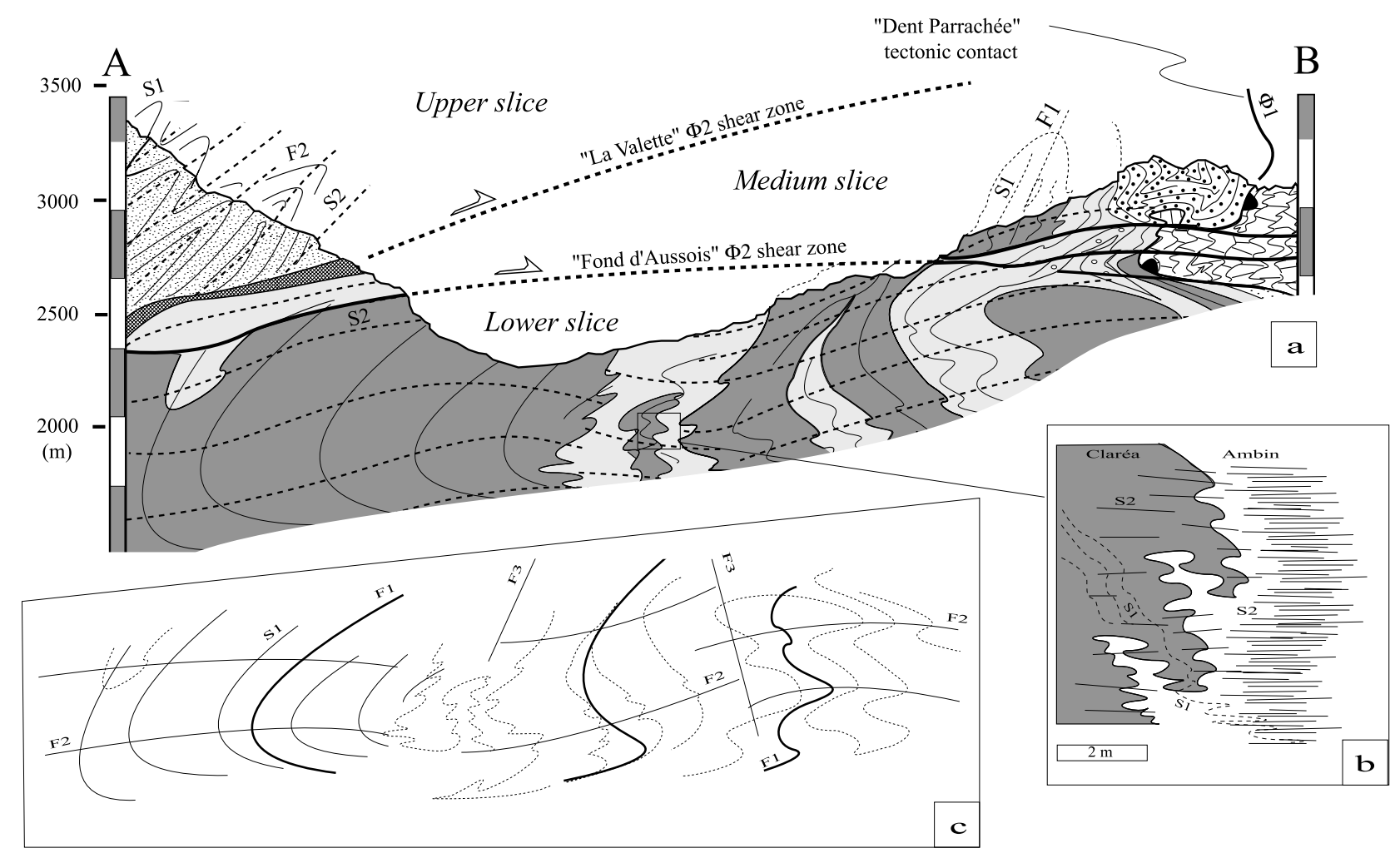

Fig. 6. Geological cross-section through the Fond d'Aussois area showing the stacking of three main slices (upper, medium and lower slices). Claréa and Ambin Groups do not follow a regular dome structure but are implicated in imbricate large-scale $\mathrm{F}_{1}$ isoclinal folds (steeply-dipping axial plans and associated $S_{1}$ fabric), which predate the main $S_{2}$ foliation (Fig. 5b). $F_{1}-F_{2}$ interference patterns (Fig. 5c) are easily recognisable on map (see Fig. 4). Two major $\Phi_{2}$ tectonic contacts have been mapped: (1) the 'Valette' shear-zone separates the basement from an overlying tectonic unit comprising a possible equivalent of the Etache group stratigraphically overlain by a thick Permian conglomerate formation (Pointe de l'Echelle, Rateau d'Aussois). (2) The 'Fond d'Aussois' shear zone cuts through the upright $F_{1}$ folds. The footwall of the 'Fond d'Aussois' shear-zone is marked by a mesoscale $F_{2}$ fold. The $F_{2}$ fold is characterised by the growth of glaucophane + chloritoid in its axial plan. The early $\mathrm{D}_{1}$ 'Dent Parrachée nappe', constituted by Liassic formations, tectonically overlies the eastern flank of the basement and attached discontinuous lenses of Triassic quartzites and dolomites. This latter contact is intensely folded by $\mathrm{D}_{2}$ (the flat-lying $\mathrm{S}_{2}$ being axial planar to these folds) and carried toward the east by the 'Fond d'Aussois' shear zone.

in microlithons between $S_{1}$ plans (Fig. 9d), outlined by muscovite or brown biotite, sometimes by pseudomorphs of staurolite. The early $S_{1}$ alpine foliation is parallel to early $\Phi_{1}$ tectonic features including the contact between the 'Dent Parrachée nappe' and the Scythian quartzites of l'Arête de l'Eché (Fig. 5). It corresponds also to the axial plane of $F_{1}$ upright folds, of metre to kilometre scale, transposing the Claréa-Ambin Group contact (Fig. 6a). The axial direction of the $F_{1}$ folds is scattered between N.160 and N.35, as shown by the cartography of the Claréa-Ambin Group contact in the lowest slice of Fond d'Aussois (Fig. 5). Such scattering is the result of interference between the $F_{1}$ and $F_{2}$ folds (Fig. 6c).

The $\mathrm{D}_{2}$ deformation is strongly expressed in the Ambin Group (Fig. 6c), developing, at all scales of observation, $\mathrm{S}_{2} / \mathrm{C}_{2}$ shear fabrics in the axial plane of $\mathrm{F}_{2}$ sub-horizontal isoclinal folds. The $S_{1}$ foliation, outlined by fibres of phengite, is badly preserved in microlithons between the $\mathrm{S}_{2} / \mathrm{C}_{2}$ planar fabric. The $\mathrm{L}_{2}$ lineation on $\mathrm{S}_{2} / \mathrm{C}_{2}$ planes indicates a direction of movement toward the ESE (Fig. 5). It consists of stretched quartz aggregates or the greenschistfacies mineral association chlorite-phengite \pm chloritoid.
This $\mathrm{D}_{2}$ deformation is locally concentrated in shear-zones, of metre to decametre scale ('Fond d'Aussois' and 'La Valette' $\Phi_{2}$ shear zones). The operation of both shear zones during the $\mathrm{D}_{2}$ shear event seems to have occurred at different structural levels and metamorphic conditions:

- the operation of the 'Fond d'Aussois' shear zone is contemporaneous with the formation of the intra-slice large-scale fold structures. The fold of 'Fond d'Aussois', outcropping in the lowest slice of the Fond d'Aussois area (Figs. 5 and 10), is one of the most spectacular examples of $D_{1}-D_{2}$ interference structure recognised in the Ambin and South Vanoise massifs. This upright fold, consisting of a core of Claréa Group, corresponds originally to the hinge of a $F_{1}$ fold that has subsequently been turned back and sheared at its top by the operation of the 'Fond d'Aussois' shear zone. The $\mathrm{S}_{2} / \mathrm{C}_{2}$ fabric, badly expressed in this core of Claréa micaschist, is defined by a discrete alignment of glaucophane, chlorite, phengite and chloritoid in the axial plane of open $\mathrm{F}_{2}$ folds transposing the $S_{1}$ foliation (Fig. 9). The $L_{2}$ mineral lineation, carried by the $S_{2} / C_{2}$ fabric, is marked by 


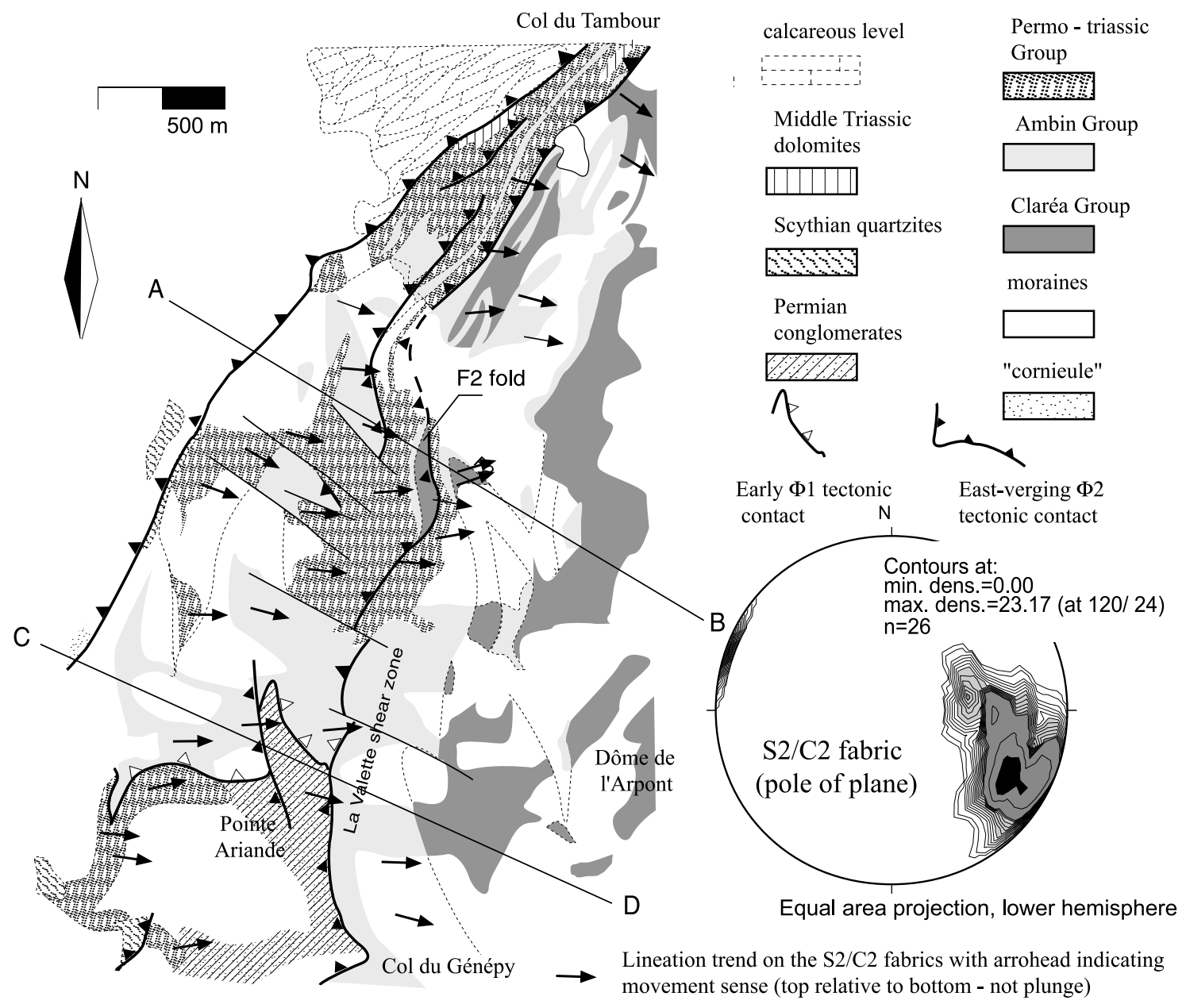

Fig. 7. Geological map of the La Valette area; location: 'C' in Fig. 1. The $D_{3}$ doming of the south Vanoise massif has steepened the $S_{2} / C_{2}$ fabrics, which at present dips steeply west. The interference pattern between $\mathrm{F}_{1}$ and $\mathrm{F}_{2}$ folds, not easily recognisable on map, is shown on A-B and C-D cross-sections (see Fig. 8). Note the $F_{2}$ fold cross-cut by the 'La Valette' shear zone.

glaucophane-chloritoid and phengite growing in N.095 orientation. The 'Fond d'Aussois' shear zone can be considered as an early $\mathrm{D}_{2}$ shear zone, syn-metamorphic during crystallisation of glaucophane.

- the operation of the 'La Valette' shear zone post-dates the formation of the intra-slice large-scale fold structures. The stretched limbs of the $F_{2}$ isoclinal folds, defined in the upper slice of Fond d'Aussois by regular alternations between carbonaceous and conglomeratic levels, are cut by the shear zone. This is consistent with structural observations carried out more to the north, in the La Valette area (Fig. 1B), where the 'La Valette' shear zone cross-cuts a $F_{2}$ fold consisting of a core of Claréa Group (Figs. 7 and 8). Chemical compositions of phengites that crystallised in the 'La Valette' shear zone indicate pressures lower than for the 'Fond d'Aussois' shear zone (the complete dataset can be downloaded on http://tel.ccsd.cnrs.fr/documents/archives0/00/00/69/44/ index_fr.html). The 'La Valette' shear zone can be considered as a late $\mathrm{D}_{2}$ shear zone, formed under greenschist-facies conditions. The retrograde metamorphic assemblage, carried by the $\mathrm{D}_{2}$ shear fabrics (blueschist to greenschist facies), obviously reflects a post- $\mathrm{D}_{1}$ exhumation process.

\subsection{Ductile to brittle $D_{3}$ stage}

A late, post- $\mathrm{D}_{2}$ event, deforms the tectonic pile of Fond d'Aussois. It consists of large-scale undulations deforming $\Phi_{2}$ shear zones and $S_{2} / C_{2}$ fabrics (Fig. 10). Normal brittleductile faults are locally associated with this plicative deformation, as well as a crenulation or solution cleavage $\left(\mathrm{S}_{3}\right)$, which increases progressively in the south part of the massif (Plan d'Avaldam, La Fournache valley, 'nappe des cornieules'; Fig. 11). Pre-existing $\mathrm{D}_{2}$ structures exhibit a staircase geometry: alternation between sub-horizontal, or shallowly SE-dipping steps, and steeply-dipping jumps associated with an intense $\mathrm{S}_{3}$ crenulation. Close to Termignon, $\mathrm{D}_{2}$ structures are straightened out to the vertical, and disappear bellow the gypsum formation of the Arc valley. A roll-over of $\mathrm{D}_{2}$ structure at the footwall and hanging-wall of the brittle Arc fault is strongly suspected to 


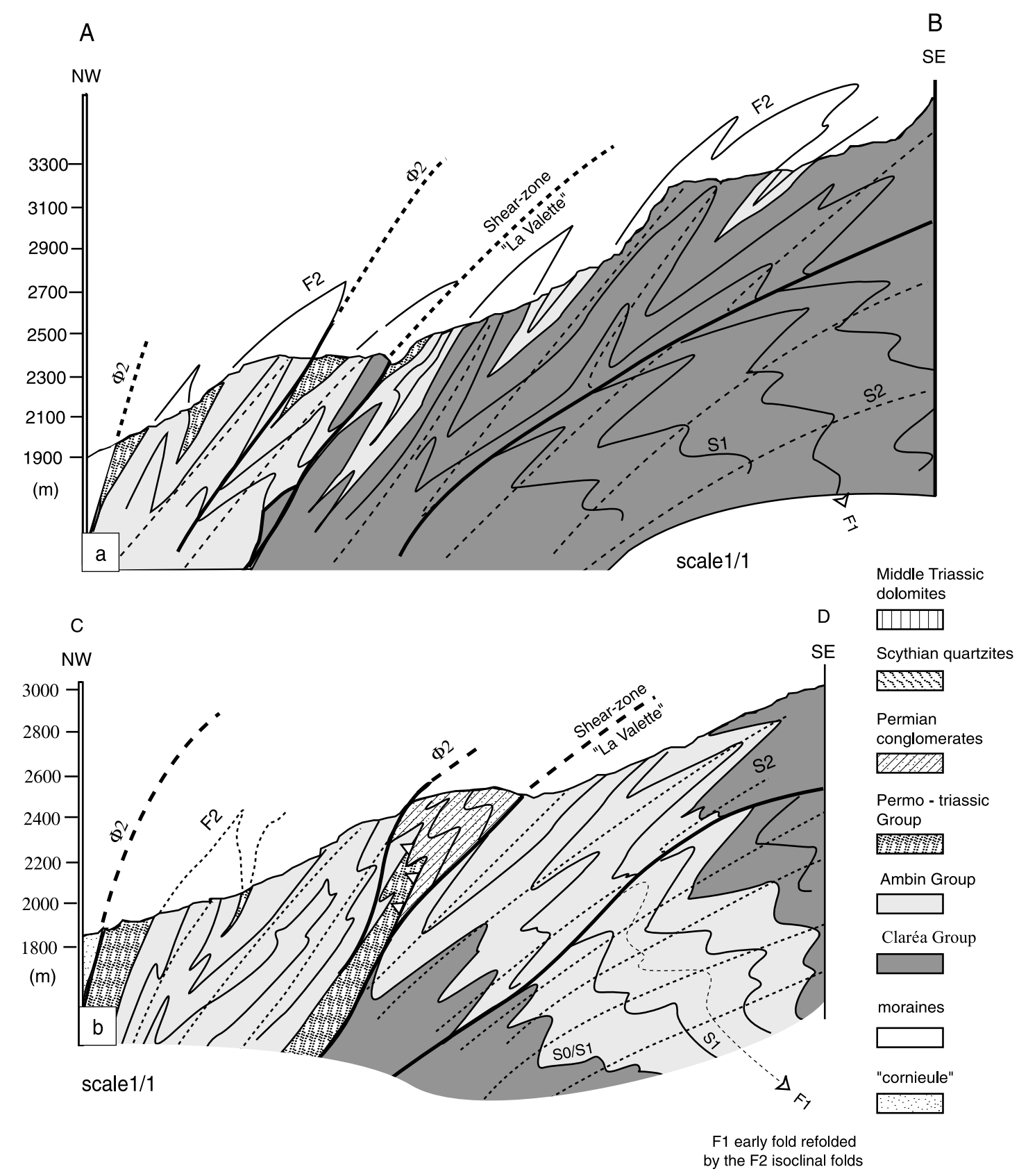

Fig. 8. E-W geological cross-sections through the La Valette area, showing $\mathrm{F}_{1}-\mathrm{F}_{2}$ fold interference. The repetition of thin levels of Ambin microconglomerates within the massive metapelitic Claréa Group (cross-section A-B) can be explained by interference between pre-existing large-scale $\mathrm{F}_{1}$ folds (fan-shaped edifice of $F_{1}$ folds shown on Fig. 10) and E-verging $F_{2}$ recumbent folds affecting the limbs of the $F_{1}$ folds (cross-section $C-D$ ).

explain the doming of the Ambin and south Vanoise massifs (work in progress).

\section{Discussion}

\subsection{Tectonic evolution of the basement domes}

Structural investigations carried out in parallel in the Ambin and South Vanoise massifs appear strongly consistent. They yield a coherent tectonic pattern resulting from $\mathrm{D}_{2}$ deformation partitioning and differences in preservation of $\mathrm{D}_{1}$ structure, that have been clearly evidenced between the core and the rim of the Ambin dome.

\subsection{1. $D_{2}$ partitioning of deformation}

From top to bottom of the tectonic piles, a clear structural layering was thus observed (Fig. 12): (i) $S_{2}$ and $D_{2^{-}}$to $D_{3^{-}}$ related shear bands are dominant in the Schistes Lustrés Nappe surrounding the domes. (ii) $S_{2}$ is superimposed on a well-preserved $S_{1}$ in the Ambin Nappe (Briançonnais cover slices + pre-Permian slices of Ambin and Claréa Groups 

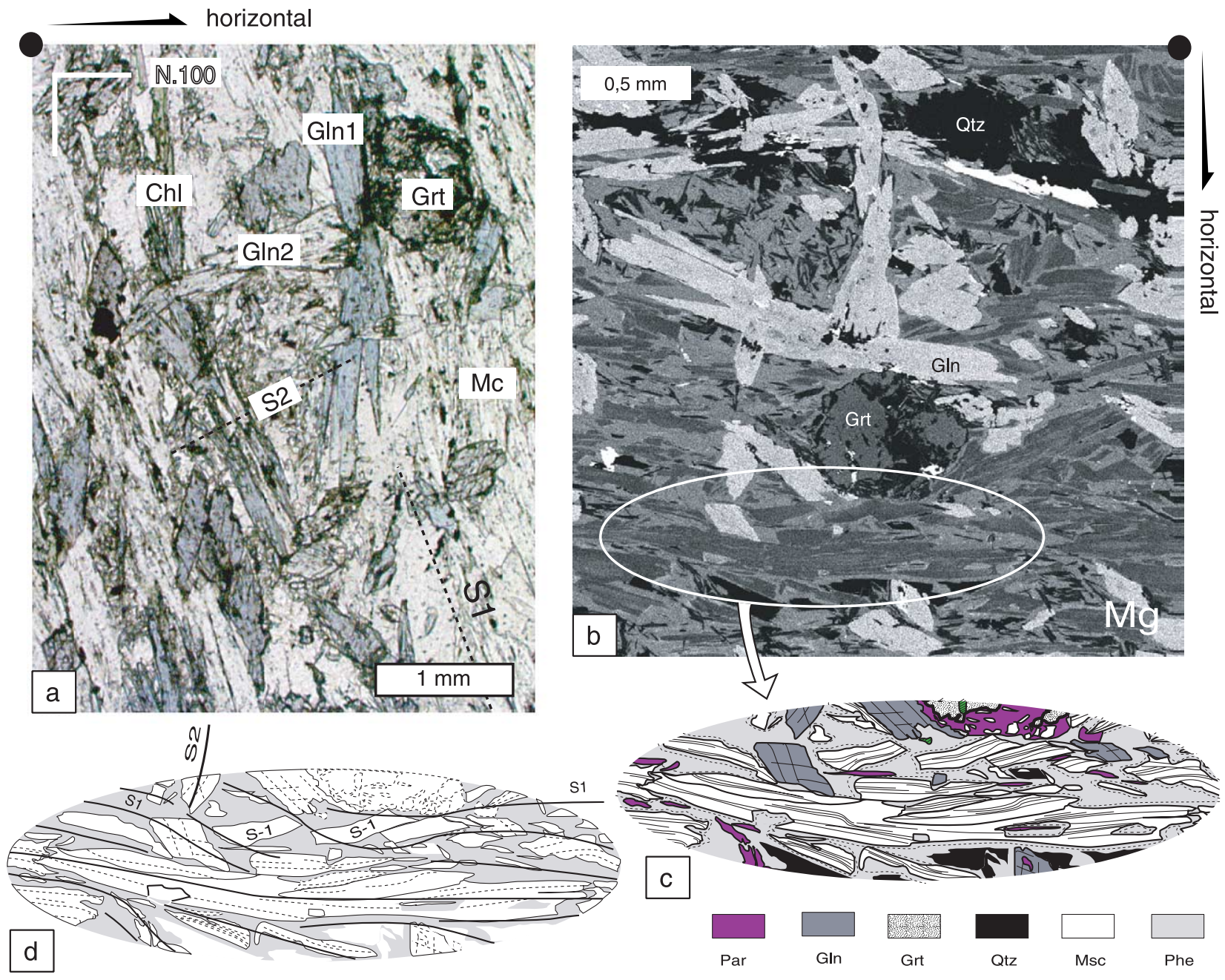

Fig. 9. Distribution of Fe-glaucophane in the same thin section (sample Ga-78: glaucophane-bearing micaschist sampled in the footwall of the 'Fond d'Aussois' shear-zone, South Vanoise massif). (a) Microphotographs showing the relationship between the discrete $S_{2}$ fabric (blueschist assemblages with glaucophane, phengite, paragonite, \pm chloritoid, growing often in veins of chlorite-quartz) and the main steeply-dipping $S_{1}$ foliation (garnet, glaucophane, phengite, paragonite, \pm chloritoid, \pm chlorite, \pm clinozoisite, \pm jadeite). (b) X-ray map of microphotograph a: relative content of magnesium (Mg) varying from low (dark) to high (white); note that Gln1 and Gln2 are indistinguishable on X-ray maps (same composition). Grt: alpine garnet, Gln1: $\mathrm{D}_{1}$-related glaucophane, Gln2: $\mathrm{D}_{2}$-related glaucophane, Chl: chlorite, Msc: inherited muscovite, Mc: mixing between high-P alpine phengites and destabilised inherited muscovite, Qtz: quartz. (c) and (d) Sketch detailing the microstructural and mineralogical relationships between the $\mathrm{S}_{-1}$ pre-alpine fabric, badly preserved in microlithons, and the pervasive $S_{1}$ alpine fabric. Note that the pre-alpine muscovites (Msc), outlining the $S_{-1}$ fabric, are destabilised at their expense by alpine phengite (Phe) and paragonite (Par). The complete chemical dataset can be downloaded by readers using the following URL address: http://tel.ccsd.cnrs.fr/ documents/archives0/00/00/69/44/index_fr.html.

mixed together). $S_{2}$ is dominant in the upper part of the Ambin Nappe defined in the Ambin massif, leading to an almost complete transposition, together with $\Phi_{2}$ shear zones. $\mathrm{S}_{2}$ is less pervasive at the bottom of the Ambin Nappe studied in the Fond d'Aussois area, leading to an incomplete transposition of the $D_{1}$ fabric between the $\Phi_{2}$ shear zones (spectacular $D_{1}-D_{2}$ interference features). It is during $\mathrm{D}_{2}$ deformation that the $\mathrm{F}_{1}$ folds of the Fond d'Aussois area are straightened out to the vertical and sheared. The $\mathrm{D}_{2}$ E-verging simple shear is locally concentrated in shear-zones formed under blueschist ('Fond d'Aussois' shear zone) to greenschist-facies conditions ('La Valette' shear zone). (iii) The gently dipping foliation that occurs in the very core of the Ambin dome formed by the Claréa Nappe was interpreted as a penetrative alpine $S_{1}$ fabric with characteristic HP mineral assemblages that grades upward to $D_{1}-D_{2}$ interference features.

\subsubsection{Geometry and kinematics of the early $D_{1}$ alpine tectonic contacts}

$\mathrm{D}_{1}$ is the earliest alpine ductile deformation recognised so far in the field. It is well preserved in the deepest part of the Ambin massif (i.e. the Claréa Nappe) whereas in the overlying units (i.e. the Schistes Lustrés and Ambin Nappes) a more or less complete transposition occurred during $\mathrm{D}_{2} . \mathrm{D}_{2}$ shearing, strongly expressed at the top of the domes, grades downward to large-scale $\mathrm{D}_{1}-\mathrm{D}_{2}$ interference features characterising the tectonic pattern of the Fond 


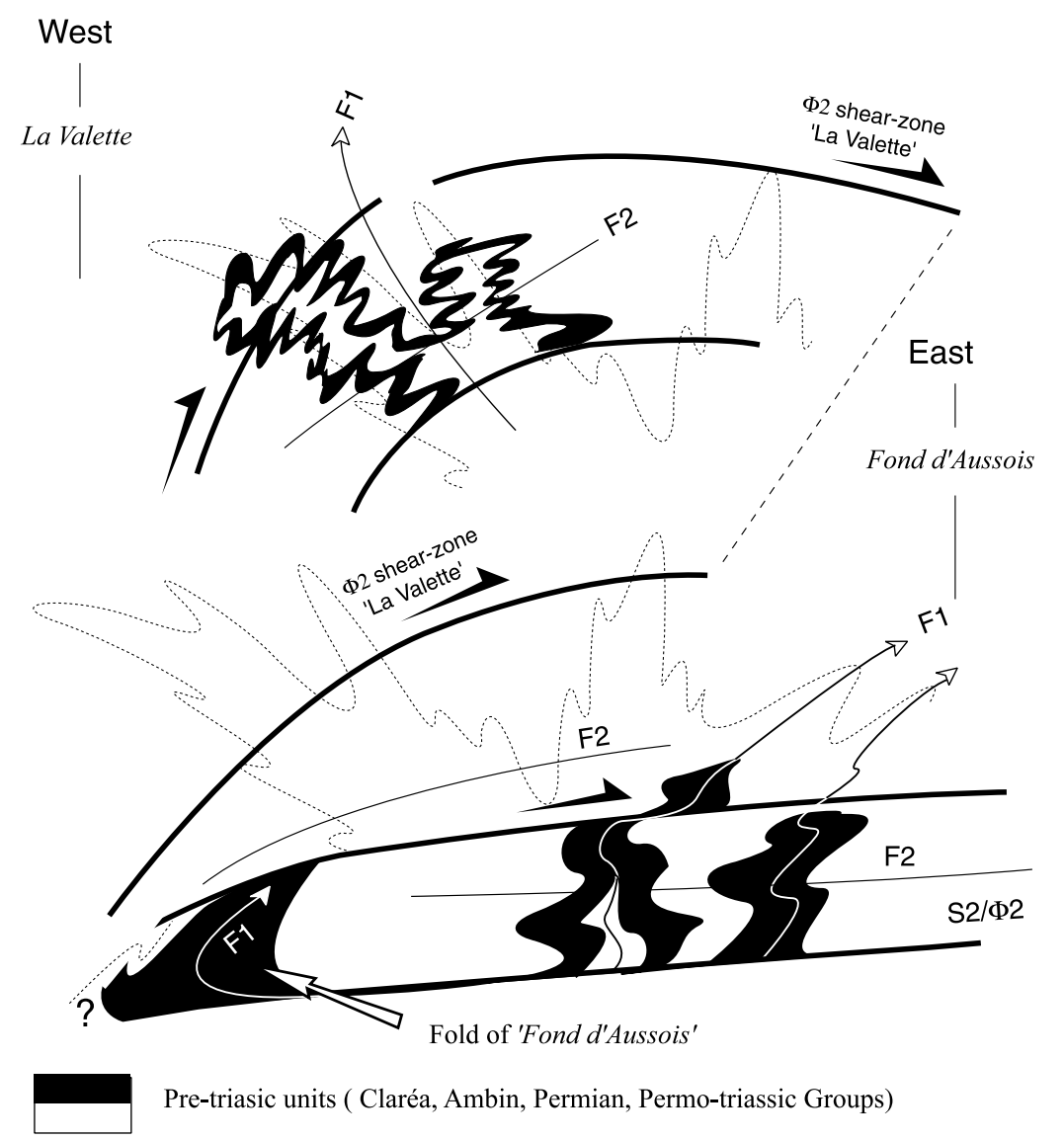

Fig. 10. Summary of structural information, collected in the western part of the South Vanoise massif, across two synthetic E-W geological cross-sections (La Valette and Fond d'Aussois areas). A $D_{1}$-related fan shaped edifice of $F_{1}$ folds can be imaged. Such geometry could be interpreted, in first approximation, as resulting from a vertical tectonic process. It corresponds in fact to a flat-lying nappe- and folds edifice, which has been subsequently steepened by $\mathrm{D}_{2}$ shearing and then weakly fanned out by $D_{3}$ doming. Note that in both areas, $D_{2}$ shearing is responsible for the development of spectacular $F_{1}-F_{2}$ fold interference patterns, including the 'Fond d'Aussois' fold discussed in the text.

d'Aussois area. Exposure conditions of the deepest parts of the South Vanoise massif (i.e. the equivalent of the Claréa Nappe in the Ambin massif) do not allow recognition of the original flat-lying geometry of the $\mathrm{D}_{1}$ nappe edifice as in the Fond d'Aussois area. This early geometry has been inferred from the deepest part of the Ambin massif, which preserves HP-LT structures related to a $\mathrm{D}_{1}$ event forming horizontal nappes. $\mathrm{D}_{1}$ in the Claréa Nappe corresponds to a noncoaxial deformation with a dominant near-horizontal $\mathrm{N}-\mathrm{S}$ component. The N-S component is suggested by the $\mathrm{L}_{1}$ lineation. This direction is similar to that observed in the less metamorphosed external units of the north Penninic domain (Baudin et al., 1993; Ceriani et al., 2001) and consistent with slip vectors deduced from geodynamic reconstruction (Platt et al., 1989).

\subsection{Toward a model of exhumation for alpine HP-rocks}

Can we interpret and fit field observations of early $\mathrm{D}_{1}$ fabrics, presented at the scale of the Ambin and South Vanoise massifs, into a general model for exhumation of HP-rocks? Several mechanisms have already been proposed in the literature to explain the exhumation of alpine high pressure units (for review see Platt (1993)): erosion and isostatic adjustment (Ernst, 1971; England and Richardson, 1977); tectonic denudation without lithospheric delamination (Merle and Ballèvre, 1992; Avigad et al., 1993; Michard et al., 1993), corner flow circulation within the accretionary wedge (Cowan and Shilling, 1978; Cloos, 1982; Platt, 1986), crustal extrusion related to indentation during convergence (Merle and Guillier, 1989), or forced return flow along the Benioff plane (Dal Piaz et al., 1972; Michard et al., 1993). For the deepest and most important part of the exhumation trajectory, Duchêne et al. (1997) have shown that the chronology of the retrogressive metamorphism excludes gravitational collapse as the major exhumation mechanism. According to the same authors, material balance and structural arguments also exclude isostatically assisted erosion processes. Subduction dynamics and tectonically assisted erosion are the most likely mechanisms accounting for the exhumation. Isostasyassisted erosion and shallow-level extension are nevertheless required to eventually bring the high-pressure rocks to the exposure. In the Alpine collisional belt, geological, 


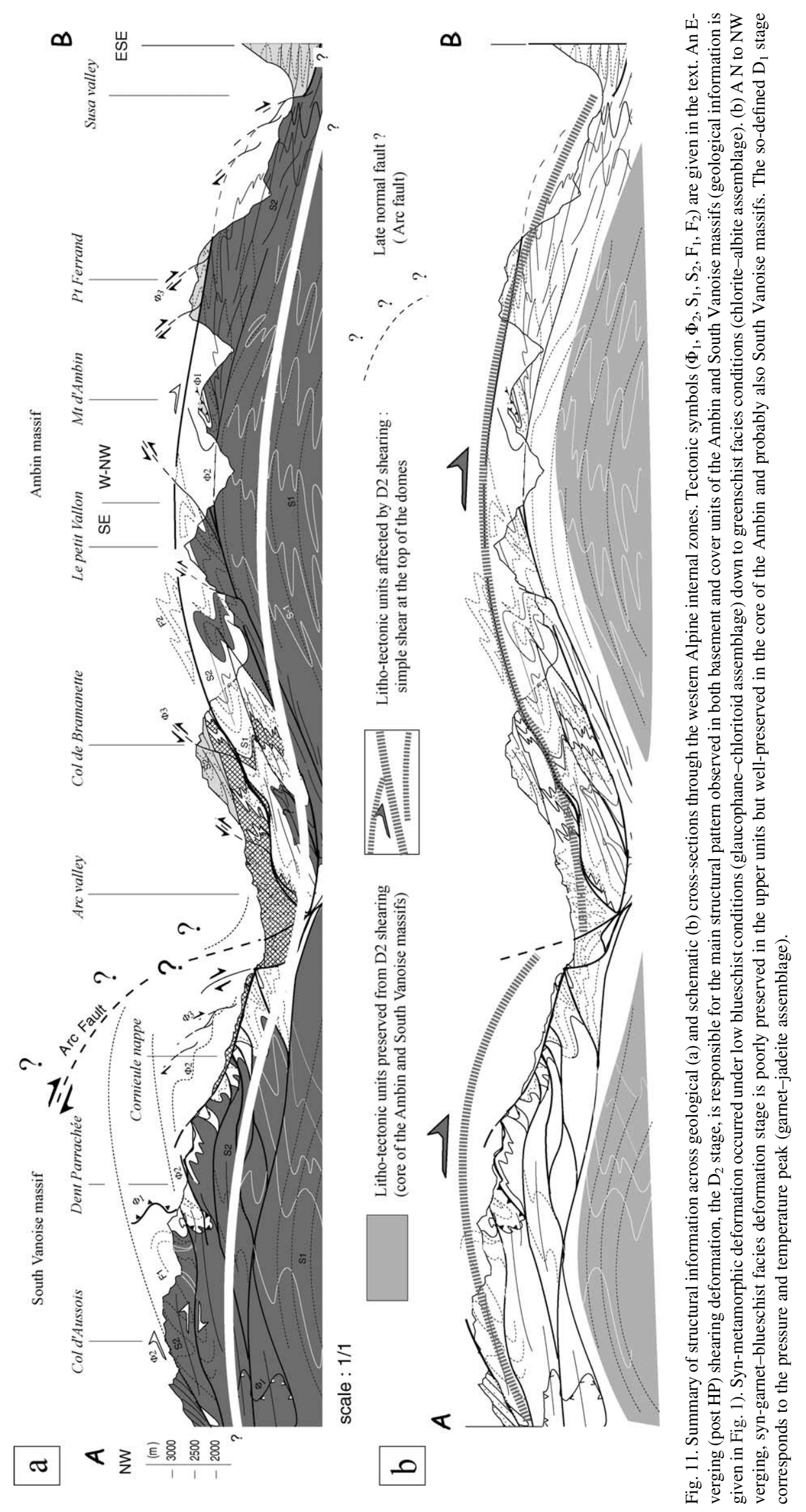




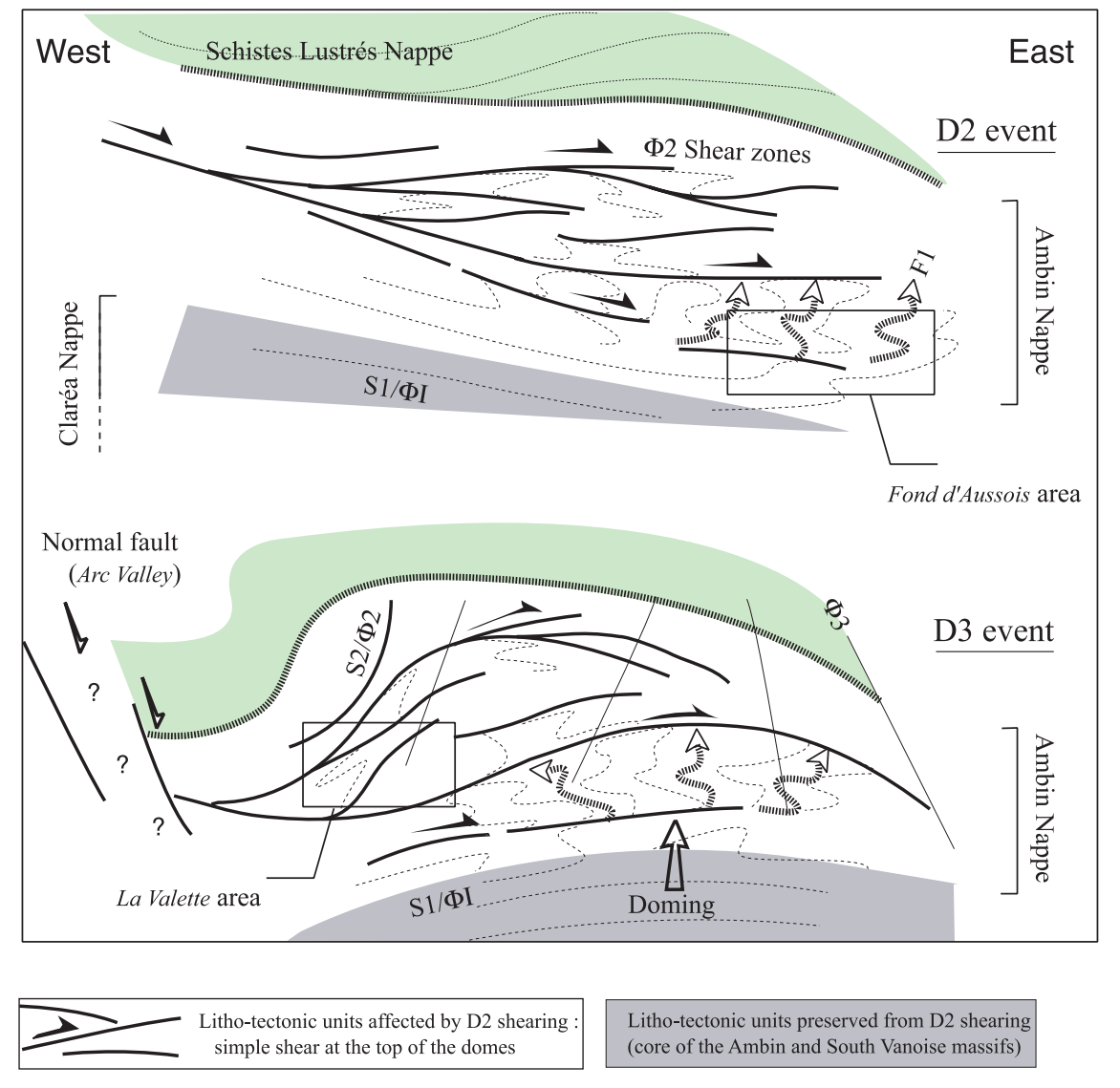

Fig. 12. Synthetic sketch to explain the doming of the Ambin and south Vanoise massifs by roll-over on both side of the Arc valley. The extensional geometry of $D_{2}$ fabrics before $D_{3}$ doming is discussed in previous papers (Ganne et al., 2003; 2004). Note that $D_{2}$ shearing decreases downward in the core of the massifs (bottom of the Ambin Nappe), leading to the development of spectacular $\mathrm{D}_{1}-\mathrm{D}_{2}$ interference features. At the western part of the South Vanoise massif (Fond d'Aussois area; Fig. 4), the $\mathrm{D}_{1}-\mathrm{D}_{2}$ interference features are outlined by the Ambin and Claréa Group contacts and are easily recognisable. This is not the case in the western part of the Ambin massif where the contact between the Ambin and Claréa Group is sheared by $D_{2}$ (see Fig. 2a).

petrological and chronological evidences indicate that $\mathrm{HP}-$ LT metamorphic rocks have been generated in the subduction zone which existed before the collisional event (see Dal Piaz and Lombardo (1986), Polino et al. (1990) or Pognante (1991) for reviews). From these data, two main models have been developed and numerically explored in which blueschist and eclogite facies rocks were formed then exhumed while subduction of oceanic lithosphere was still active.

\subsubsection{Low-angle thrusting synthetic to the subducted plate}

The most classic model showing the effects of both simple shear and pure shear during simultaneous underplating of the lithosphere and exhumation of the upper crust (Fig. 13a) has been proposed for the Alps by Escher and Beaumont (1997). These authors take up and elaborate the model of Epard and Escher (1996) to give a geometrical and mechanical explanation for the initiation and subsequent exhumation and stacking of basement nappes. Their model is based on several geological factors and previously published ideas. An essential consideration is that originally deep basement rocks displayed a penetrative early foliation and stretching lineation, implying strong deformation throughout most of the rock volume. The model of Escher and Beaumont for the Alps resembles that of Chemenda et al. (1995) inasmuch as they also suggest that a slice of upper continental crust is detached at the front of the subducted lithosphere and that this slab moves back to the surface while the rest of the lithosphere continues to be subducted. The mechanism of ascent is, however, different as it is proposed that buoyancy forces and erosion only assist the process but are not the dominant factor. Instead it is proposed, similarly to the channel flow model, that exhumation of the detached crustal slab is the result of combined simple shear and pure shear. In other words, once a crustal slab is detached from the subducting lithosphere, further descent of this slab is hindered at a certain point and these now high-grade rocks are then flattened through pure shear between the two converging plates. The flattening of the slab implies a decrease in thickness and an increase in length. The additional length cannot be accommodated downwards and the slab is thus laterally expulsed or 'squeezed out' to the surface. 

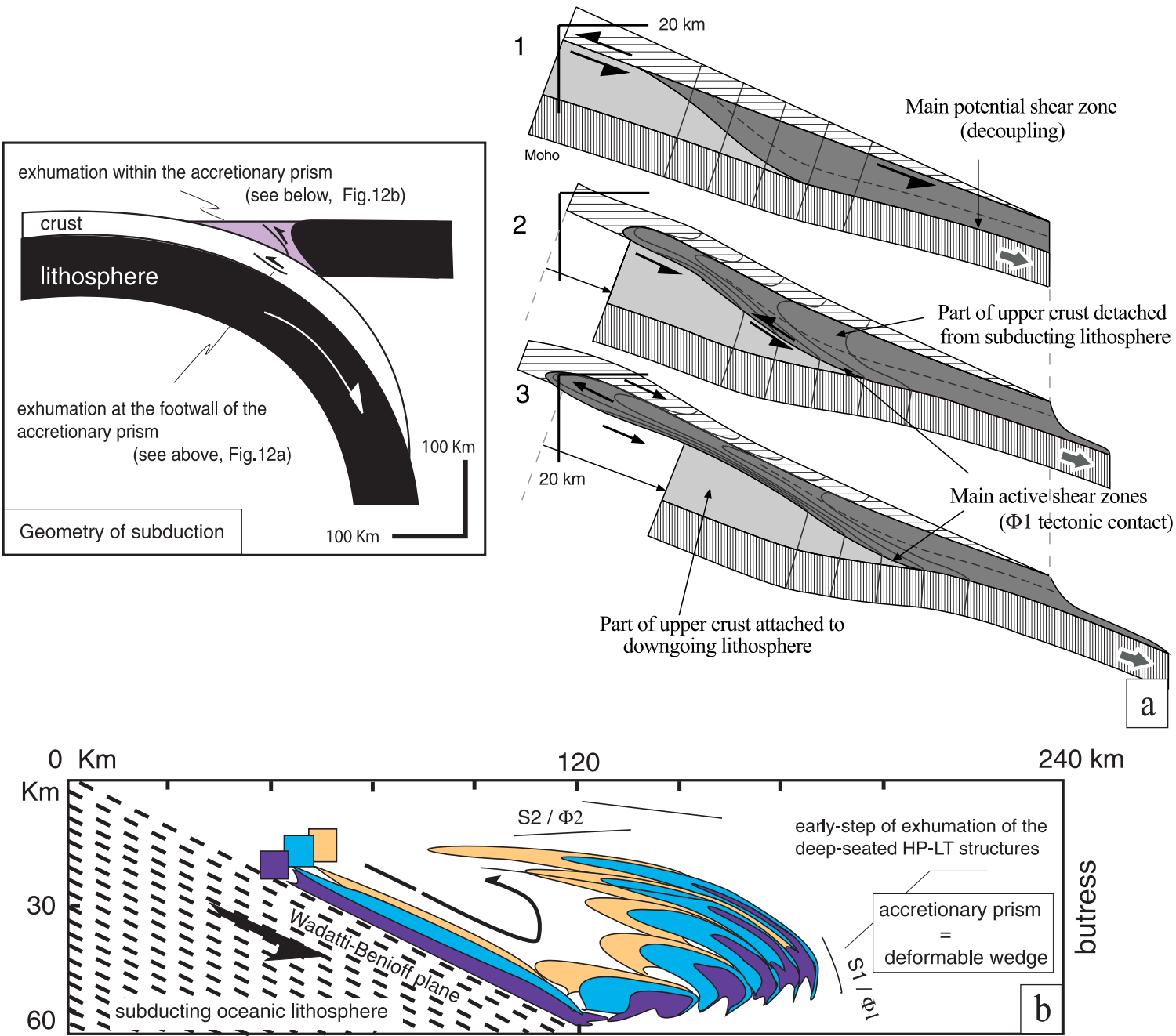

Fig. 13. Dynamic of subduction and mechanism for exhumation of alpine HP-rocks. (a) Near-horizontal thrusting synthetic to the subducted plate. Twodimensional reconstruction showing the geometric consequence of combined simple and pure shear in a system envisaged to have generated the extrusion of nappe in the Alps (s.s.). Stage 1 is similar to stage 1 in the model of Chemenda et al. (1995). Also in this model, Escher and Beaumont (1997) propose that buoyancy forces assist the oblique escape of deep-seated material but are not considered as the dominant factor. (b) Geometry, parameter and mechanism of the corner flow model (Cloos, 1982), numerically explored by Allemand and Lardeaux (1997), modified. The different stages of deformation as well as the geometry of structures associated (deep-seated $S_{1}$ foliation, early $\Phi_{1}$ slices, late flat-lying $S_{2}$ fabric and $\Phi_{2}$ shear-zones) are predicted by the numerical model.

\subsubsection{Vertical extrusion induced by the dynamics of the prism}

Another popular model assumes that rocks are buried then uplifted within an accretionary prism overlying the subduction zone (Fig. 13b). The corner flow model has been proposed by Cowan and Shilling (1978) and numerically explored by Cloos (1982) and then Allemand and Lardeaux (1997) to discuss its application to the internal part of the Alps, taking into account the metamorphic, structural and geochronological data. Both analogue and numerical models show that prisms are affected by internal deformation. The flow pattern is sustained by the continuing subduction and is limited by the hanging wall, which acts as a rigid buttress (Platt, 1986), or induces channel flow in a small angle wedge (Cloos, 1982). Prism mechanisms seem to represent an efficient way of uplifting rocks trapped as fragments of oceanic and continental crust. They differ from the previous mechanisms by: (1) the existence of very strong velocity gradients, which allows rocks metamorphosed at different pressure conditions to be brought in contact; (2) the capability of prisms to operate at a steady state. As the shape of the prism is controlled by equilibrium between tectonic forces, progressive underplating must be compensated by either erosion or near-surface extension (Davis et al., 1983; Platt, 1986). The characteristic time of the exhumation is scaled by the subduction rate and should be in the order of a few million years (Cloos, 1982; Allemand and Lardeaux, 1997). Early exhumation of eclogite and blueschist facies rocks, most probably while subduction is still active, is expected (Platt, 1986). To portray the strain partitioning related to this velocity field the evolution of the shape of an initial circular object has 
been studied by the authors. This object behaves as a passive marker that in cross-section has the surface of an Alpine nappe scaled to the model. The exhumation phase begins by the development of a 'head' in the internal part of the wedge and of a 'tail', which remains attached at the base of the wedge. The development of the 'head' results from the decrease of the horizontal component of the velocity and the increase of the vertical component of the velocity at the base of the wedge. The associated fabric would be vertical. When the head finally enters the extensional field ( 0 to $\sim 15 \mathrm{~km}$ ), it becomes progressively elongated. The associated fabric would be horizontal. This evolution is independent from the initial shape of the object. From a metamorphic point of view, each phase will overprint the pre-existing structure, and relics of structure will thus not be interpretable in terms of kinematics at the scale of the outcrop.

\subsubsection{Summary}

Spatial and kinematic variations of fabric orientation predicted by both models provide key elements for understanding the overall deformation history of the western Penninic domain. Despite the different mechanisms involved in exhumation, the models yield a fundamental result, strongly consistent with our structural data. The early steps of exhumation of HP-rocks will develop a strongly penetrative and non-coaxial deformation, corresponding to the $\mathrm{D}_{1}$ event in the Ambin and South Vanoise massifs. The major difference is in the geometry and in the preservation of this $\mathrm{D}_{1}$-related HP-fabric. The corner flow model predicts a reworking of the deep-seated steeply-dipping slices subsequent to their vertical extrusion. Conversely, the model of Escher and Beaumont (1997) assumes low-angle forethrusting for the initiation and subsequent exhumation and stacking of basement nappes.

Field data, performed in the core of the Ambin and South Vanoise domes, led us to favour Escher and Beaumont's (1997) model as the best candidate accounting for the development and preservation of flat-lying HP-nappes. However, it must be kept in mind that our choice is strongly dependant on the numerical result of Allemand and Lardeaux (1997), which shows that during the exhumation processes, the deep-seated slices will preferentially undergo an obliteration of their steeply-dipping fabric rather than a gentle tilting into a horizontal position. New computing of corner flow circulation, taking into account the difference in rheology between units and their variations of density and viscosity with depth, should therefore be tested.

\section{Conclusion}

Data and field observations of early HP-LT horizontal structures and a related nappe-forming event, presented at the scale of the Ambin and South Vanoise massifs, are still difficult to interpret and to fit with certainty into a general model. There are still too few constraints, in the western Penninic domain, on the initial geometry of the slices of continental and oceanic crust formed during the early alpine steps of exhumation, and that might be compared with our $\mathrm{D}_{1}$ HP-nappes. In the more internal units of the western Penninic domain (e.g. Gran Paradiso), the corresponding $D_{1}$ kinematics (or equivalent according to authors) become highly hypothetic and previous observations are often totally contradictory (Choukroune et al. (1986) or Platt et al. (1989) for different interpretations), due to the post- $\mathrm{D}_{1}$ intense transposition features (Lefèvre and Michard, 1976; Philippot, 1990; Henry et al., 1993; Rolland et al., 2000; Agard et al., 2001; Wheeler et al., 2001; Reddy et al., 2003). Despite the lack of other critical examples to corroborate our assumption, we propose to regard the geometric and kinematic characteristics of the Ambin and South Vanoise HP-nappes as representative of the early alpine steps of exhumation in the western transect of the Alpine chain (s.s.). Our assumption strongly relies on the now well-constrained geometry and kinematics of the north Penninic nappes (Baudin et al., 1993; Ceriani et al., 2001). The non-coaxial and flat-lying HP-structures observed in the core of the Ambin massif suggest that they were probably acquired during the ascent path, along a gently dipping slope. We may therefore speculate that the early steps of HP-rocks exhumation induced some kind of flat-lying nappes with an overall $\mathrm{N}$ to $\mathrm{NW}$-directed movement, as classically advocated in previous models (e.g. Escher and Beaumont, 1997), rather than protracted extrusion of vertical (or fanshaped) slices (Allemand and Lardeaux, 1997).

\section{Acknowledgements}

The authors are grateful to J. Clulow, G. Rosenbaum and V. Toy for their critical reading. We also express grateful thank to D. Marquer and S. Schmid for their discussions and encouraging advice. J.M. Lardeaux and N. Froitzheim are thanked for their constructive reviews. This study was funded by the GéoFrance3D program (INSU, BRGM, MNERT).

\section{References}

Agard, P., Jolivet, L., Goffé, B., 2001. Tectonometamorphic evolution of the Schistes Lustrés complex: implications for the exhumation of HP and UHP rocks in the Western Alps. Bulletin de la Société Géologique de France 5, 617-636.

Allemand, P., Lardeaux, J.M., 1997. Strain partitioning and metamorphism in a deformable orogenic wedge: application to the Alpine belt. Tectonophysics 280, 157-169.

Allenbach, B., 1982. Géologie de la Bordure SW du massif d'Ambin (Alpes occidentales). Ph.D. thesis, Strasbourg, 138pp.

Avigad, D., Chopin, C., Goffé, B., Michard, A., 1993. Tectonic model for the evolution of the Western Alps. Geology 22, 762-763. 
Baudin, T., Marquer, D., Persoz, F., 1993. Basement-cover relationships in the Tambo Nappe (Central Alps, Switzerland): geometry, structure and kinematic. Journal of Structural Geology 15, 543-553.

Berthé, D., Choukroune, P., Jégouzo, P., 1979. Orthogneiss, mylonite and non-coaxial deformation of granites: the example of the South Armorican Shear Zone. Journal of Structural Geology 1, 31-42.

Bertrand, J.M., Pidgeon, R.T., Leterrier, J., Guillot, F., Gasquet, D., Gattiglio, M., 2000. SHRIMP and IDTIMS U-Pb zircon ages of the preAlpine basement of the Internal Western Alps (Savoy and Piemont). Schweizerische Mineralogische und Petrographische Mitteilungen 80 225-248.

Borghi, A., Gattiglio, M., Mondino, F., Zaccone, G., 1999. Structural and metamorphic evidences of pre-Alpine basement in the Ambin nappe (cottian Alps, Italy). Memorie de Scienze Geologiche Italiana Padova 51, 205-220.

Caron, J.M., 1974. Rapports entre diverses 'générations' de lawsonite et les déformations dans les Schistes Lustrés des Alpes cottiennes septentrionales (France et Italie). Bulletin de la Société Géologique 7, 255263.

Caron, J.M., 1977. Lithostratigraphie et tectonique des Schistes Lustrés dans les Alpes cottiennes septentrionales (France et Italie). Bulletin de la Société Géologique 16, 255-268.

Ceriani, S., Fügenschuh, B., Schmid, S.M., 2001. Multi-stage thrusting at the 'Penninic Front' in the Western Alps between Mont Blanc and Pelvoux massifs. International Journal of Earth Sciences 90, 685-702.

Chemenda, A., Mattauer, M., Malavieille, J., Bokun, A.N., 1995. A mechanism for syn-collisional rock exhumation and associated normal faulting: result from physical modelling. Earth and Planetary Science Letters 132, 225-232.

Choukroune, P., Ballèvre, M., Cobbold, P., Gautier, Y., Merle, O., Vuichard, J.P., 1986. Deformation and motion in the Western Alps. European Journal of Mineralogy 3, 263-269.

Cloos, M., 1982. Flow melanges: numerical modelling and geochronologic constraints on their origin in the Franciscan subduction complex, California. Bulletin of the Geological Society of America 93, 330-345.

Cowan, D.S., Shilling, R.M., 1978. A dynamic scaled model of accretion at trenches and its applications for the tectonic evolution of subduction complexes. Journal of Geophysical Research 83, 5389-5393.

Dal Piaz, G.V., Lombardo, B., 1986. Early alpine metamorphism in the Penninic Monte Rosa-Gran Paradiso basement nappes of the NorthWestern Alps, in: Evans, B.W., Brown, E.H. (Eds.), Blueschists and Eclogites Geological Society of America, Memoir, 164, pp. 249-265.

Dal Piaz, G.V., Hunziker, J.C., Martinotti, G., 1972. La Zona Sesia-Lanzo e l'evoluzione tettonico-metamorfica delle Alpi nordoccidentali interne. Memorie de Scienze Geologiche Italiana 11, 433-466.

Davis, D., Suppe, J., Dahlen, F.A., 1983. Mechanism of fold-and-thrusts belts and accretionary wedges. Journal of Geophysical Research 88, $1153-1172$

Debelmas, J., Desmons, J., Ellenberger, F., Goffé, B., Fabre, J., coll., 1989. Carte géol. France $(1 / 50,000)$, feuille Modane (775) Notice par J. Debelmas et al., 1989, 53pp.

Détraz, G., Loubat, H., 1984. Facies à disthène, staurotide et grenat dans un micaschiste appartenant à l'unité des "gneiss du Sapey" (Vanoise, alpes française). Géologie Alpine, Grenoble 60, 5-12.

Deville, E., 1987. Etude géologique en vanoise orientale (Alpes occidentales française, Savoie). De la naissance à la structuration d'un secteur de la paléo-marge européenne et de l'océan tethysien: aspects stratigraphiques, pétrographiques et tectoniques. Ph.D. thesis, Chambery, 297pp.

Duchêne, S., Lardeaux, J.M., Albarède, F., 1997. Exhumation of eclogites: insights from depth-time path analysis. Tectonophysics 280, 125-140.

Ellenberger, F., 1958. Etude géologique du pays de Vanoise (Savoie). Memoire Explicatif de la Carte Géologique de France, 561pp.

England, P.C., Richardson, P., 1977. The influence of erosion upon mineral facies of rocks from different metamorphic environments. Journal of the Geological Society of London 134, 201-213.
Epard, J.L., Escher, A., 1996. Transition from basement to cover: a geometric model. Journal of Structural Geology 18, 533-548.

Ernst, W.G., 1971. Metamorphic zonations on presumably subducted lithospheric plates from Japan, California and the Alps. Contribution to Mineralogy and to Petrology 34, 43-59.

Escher, A., Beaumont, C., 1997. Formation, burial and exhumation of basement nappes at crustal scale: a geometric model based on the Western Swiss-Italian Alps. Journal of Structural Geology 19, 955974

Freeman, S.R., Inger, S., Butler, R.W.H., Cliff, R.A., 1997. Dating deformation using $\mathrm{Rb}-\mathrm{Sr}$ in white mica: greenschist facies deformation ages from the Entrelor shear zone, Italian Alps. Tectonics 16, 57-76.

Fudral, S., Deville, E., Pognante, U., Gay, M., Fregolent, G., Lorenzoni, S., Robert, D., Nicoud, G., Black, C., Jayko, A., Jaillard, E., Bertrand, J.M., Forno, M.G., Massazza, G., 1994. Lanslebourg Mont-d'Ambin. Carte géologique de la France à 1:50,000. Ministère de l'industrie, BRGM.

Ganne, J., Bussy, F., Vidal, O., 2003. Multi-stage garnet in the internal Briançonnais basements (Ambin and South Vanoise massifs): new petrological constraints on the blueschist-facies metamorphism in the Western Alps and tectonic implications. Journal of Petrology 44, 12811308.

Ganne, J., Bertrand, J.M., Fudral, S., Vidal, O., 2004. Structural and metamorphic evolution of the Ambin massif (Western Alps): toward a new exhumation model for the Briançonnais domain. Tectonophysics, in press.

Gay, M., 1971. Le massif d'Ambin et son cadre de Schistes Lustrés (Alpes franco-italiennes). Thèse d'Etat, Lyon, 296pp.

Gebauer, D., Schertl, H.P., Brix, M., Schreyer, W., 1997. 35-Ma-old ultrahigh-pressure metamorphism and evidence for very rapid exhumation in the Dora Maira Massif, Western Alps. Lithos 41, 5-24.

Henry, C., Michard, A., Chopin, C., 1993. Geometry and structural evolution of ultra-high-pressure and high-pressure rocks from the Dora-Maira Massif, Western Alps, Italy. Journal of Structural Geology 15, 965-981.

Lefèvre, R., Michard, A., 1976. Les nappes briançonnaises internes et ultrabriançonnaises de la bande d'Acceglio (Alpes franco-italienne). Une étude structurales et pétrographique dans le faciès des schistes bleus à jadéite. Bulletin de la Société Géologique de France 29, 183222.

Lemoine, M., de Graciansky, P.C., 1988. Histoire d'une marge continentale passive: les Alpes occidentales au Mésozoïque-introduction. Bulletin de la Société Géologique de France 8 (4), 597-600.

Lister, G.L., Snoke, A.W., 1984. S-C mylonites. Journal of Structural Geology 6, 617-638.

Lister, G., Foster, M., Rawling, T., 2001. Episodicity during Orogenesis, in: Miller, J.A., Holdsworth, R.E., Buick, I.S., Hand, M. (Eds.), Continental Reactivation and Reworking Journal of the Geological Society of London, Special Publication, 184, pp. 89-113.

Malavielle, J., 1982. Etude tectonique et microtectonique de la déformation ductile dans les grands chevauchement crustaux: exemple des Alpes franco Italiennes et de la Corse. Ph.D. thesis, Montpellier, 508pp.

Markley, M.J., Teyssier, C., Cosca, M.A., Caby, R., Hunziker, J.C., Sartori, M., 1998. Alpine deformation and ${ }^{40} \mathrm{Ar} /{ }^{39} \mathrm{Ar}$ geochronology of synkinematic white mica in the Siviez-Michabel Nappe, Western Pennine Alps, Switzerland. Tectonics 17 (3), 407-425.

Meffan-Main, S., Cliff, R.A., Barnicoat, A.C., Lombardo, B., Compagnoni, R., 2004. A Tertiary age for Alpine high-pressure metamorphism in the Gran Paradiso massif, Western Alps: a $\mathrm{Rb}-\mathrm{Sr}$ microsampling study. Journal of Metamorphic Geology 22, 267-281.

Merle, O., Ballèvre, M., 1992. Late Cretaceous-early Tertiary detachment fault in the Western Alps. Comptes Rendus de l'Academie des Sciences Paris $315,1769-1776$.

Merle, O., Guillier, B., 1989. The building of the Swiss central Alps: an experimental approach. Tectonophysics 165, 41-56.

Michard, A., Chopin, C., Henry, C., 1993. Compression versus extension in the exhumation of the Dora-Maira coesite-bearing unit, Western Alps, Italy. Tectonophysics 221, 173-193. 
Michard, A., Goffe, B., Chopin, C., Henry, C., 1996. Did the Western Alps develop through an Oman-type stage? The geotectonic setting of highpressure metamorphism in two contrasting Tethyan transects. Eclogae Geologicae Helvetiae 89, 43-80.

Michel, R., 1957. Les facies à glaucophane dans le massif d'Ambin (Alpes franco-italiennes). Comptes Rendus Sommaires de la Société Géologique de France 6 (VII), 130-131.

Monié, P., 1990. Preservation of Hercynian ${ }^{40} \mathrm{Ar} /{ }^{39} \mathrm{Ar}$ ages through highpressure low-temperature alpine metamorphism in the Western Alps. European Journal of Mineralogy 2, 343-361.

Philippot, P., 1990. Opposite vergence of nappes and crustal extension in the French-Italian alps. Tectonics 9, 1143-1164.

Platt, J.P., 1986. Dynamics of orogenic wedges and the uplift of highpressure metamorphic rocks. Bulletin of the Geological Society of America 97, 1037-1053.

Platt, J.P., 1993. Exhumation of high-pressure rocks-a review of concepts and processes. Terra Nova 5, 119-133.

Platt, J.P., Lister, G.S., 1985a. Structural history of high-pressure metamorphic rocks in the southern Vanoise massif, French Alps, and their relation to Alpine tectonic events. Journal of Structural Geology 7 , 19-35.

Platt, J.P., Lister, G.S., 1985b. Structural evolution of a nappe complex, southern Vanoise massif, French Penninic Alps. Journal of Structural Geology 7, 145-160.

Platt, J.P., Lister, G.S., Cunningham, P., Weston, P., Peel, F., Baudin, T., Dondey, H., 1989. Thrusting and backthrusting in the Briançonnais domain of the Western Alps, in: Coward, M., Dietrich, D., Park, R.G. (Eds.), Alpine Tectonic Geological Society Special Publication, 45, pp. 135-152.

Pognante, U., 1991. Petrological constraints on the eclogite- and blueschistfacies metamorphism and P-T-t paths in the Western Alps. Journal of Metamorphic Geology 9, 5-17.

Polino, R., Dal Piaz, G.V., Gosso, G., 1990. Tectonic erosion at the Adria margin and accretionary processes for the Cretaceous orogeny of the Alps. Mémoire de la Société Géologique de France, pp. 345-367.

Ramsay, J.G., Huber, M.I., 1983. The Technique of Modern Structural Geology, Vol. 1: Strain Analysis. Academic Press. 307pp.
Reddy, S.M., Wheeler, J., Butler, R.W.H., Cliff, R.A., Freeman, S., Inger, S., Pickles, C., Kelley, S.P., 2003. Kinematic reworking and exhumation within the convergent Alpine Orogen. Tectonophysics 365 , 77-102.

Rolland, Y., Lardeaux, J.M., Guillot, S., Nicollet, C., 2000. Extension synconvergence, poinçonnement vertical et unités métamorphiques contrastées en bordure Ouest du Grand Paradis (Alpes Franco-Italiennes). Geodinamica Acta Special Publication 13, 133-148.

Rosenbaum, G., Lister, G.S., 2005. Tectonic evolution of the western Alps from the Jurassic to the Oligocene. Earth Science Reviews, in press.

Rubatto, D., 1998. Dating of pre-Alpine magmatism, Jurassic ophiolites and Alpine subductions in the Western Alps. Ph.D. thesis, ETH Zurich, 160pp.

Rubatto, D., Gebauer, D., 1999. Eo/Oligocene (35 Ma) high-pressure metamorphism in the Gornergrat Zone (Monte Rosa, Western Alps): implications for paleogeography. Schweizerische Mineralogische und Petrographische Mitteilungen 79, 353-362.

Rubatto, D., Hermann, J., 2001. Exhumation as fast as subduction? Geology 29, 3-6.

Rubatto, D., Hermann, J., 2003. Zircon formation during fluid circulation in eclogites (Monviso, Western Alps): implication for $\mathrm{Zr}$ and $\mathrm{Hf}$ budget in subduction zones. Geochemica et Cosmochimica Acta 67, 2173-2187.

Schwartz, S., Allemand, P., Guillot, S., 2001. Numerical model of the effect of serpentinites on the exhumation of eclogite rocks: insights from the Monviso ophiolitic massif (Western Alps). Tectonophysics 342, 193 206.

Stampfli, G.M., 1993. Le Briançonnais, terrain exotique dans les Alpes? Eclogae Geologicae Helvetiae 86, 1-45.

Stampfli, G.M., Mosar, J., Marquer, D., Baudin, T., Borel, G., 1998. Subduction and obduction processes in the Swiss Alps, in: Vauchez, A., Meissner, R. (Eds.), Continents and their Mantle Roots Tectonophysics, 296(1-2), pp. 159-204.

Wheeler, J., Reddy, S.M., Cliff, R.A., 2001. Kinematic linkage between internal zone extension and shortening in more external units in the NW Alps. Journal of the Geological Society of London 158, 439-443. 